\title{
Development of Improved Cathodes for Solid Oxide Fuel Cells
}

\author{
Final Report
}

H.U. Anderson

Work Performed Under Contract No.: DE-FG21-89MC26015

\author{
For \\ U.S. Department of Energy \\ Office of Fossil Energy \\ Morgantown Energy Technology Center \\ P.O. Box 880 \\ Morgantown, West Virginia 26507-0880 \\ By \\ University of Missouri-Rolla \\ 211 Parker Hall \\ Rolla, Missouri 65401
}

March 1991 
Objectives

ABSTRACT

The University of Missouri-Rolla conducted a 17 month research program focussed on the development and evaluation of improved cathode materials for solid oxide fuel cells (SOFC). The objectives of this program were:

- The development of cathode materials of improvis stability in reducing environments.

- The development of cathode materials with improved electrical conductivity.

The program was successful in identifiying some potential candidate materials: Air sinterable $(\mathrm{La}, \mathrm{Ca})(\mathrm{Cr}, \mathrm{Co}) \mathrm{O}_{3}$ compositions were developed and found to be more stable than La ${ }_{8} \mathrm{Sr}_{.2} \mathrm{MnO}_{3}$ tewards reduction. Their conductivity at $1000^{\circ} \mathrm{C}$ ranged between 30 to $60 \mathrm{~S} / \mathrm{cm}$. Compositions within the $(\mathrm{Y}, \mathrm{Ca})(\mathrm{Cr}, \mathrm{Co}, \mathrm{Mn}) \mathrm{O}_{3}$ system were developed and found to have higher electrical conductivity than $\mathrm{La}_{8} \mathrm{Sr}_{2} \mathrm{MnO}_{3}$ and preliminary results suggest that their stability towards reduction is superior. 


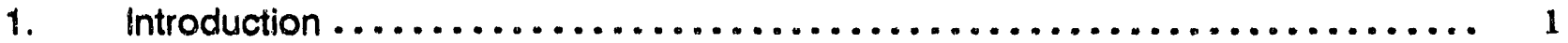

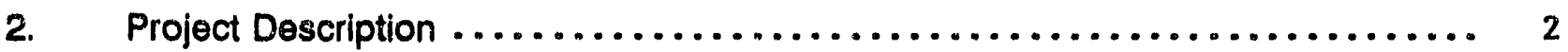

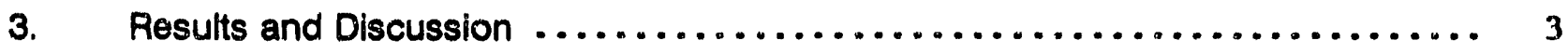

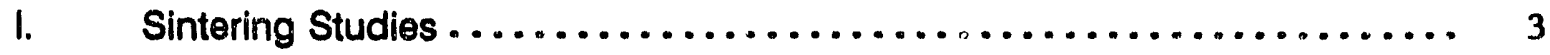

A. $\quad(\mathrm{La}, \mathrm{Ca})(\mathrm{Cr}, \mathrm{Co}) \mathrm{O}_{3}$ system $\ldots \ldots \ldots \ldots \ldots \ldots \ldots \ldots \ldots \ldots \ldots \ldots \ldots \ldots \ldots \ldots \ldots \ldots \ldots$

B. $\quad(\mathrm{Y}, \mathrm{Ca})(\mathrm{Cr}, \mathrm{Mn}, \mathrm{Co}) \mathrm{O}_{3}$ system $\ldots \ldots \ldots \ldots \ldots \ldots \ldots \ldots \ldots \ldots \ldots \ldots \ldots \ldots \ldots \ldots$

II. Electrical Conductivity Studies ........................ 6

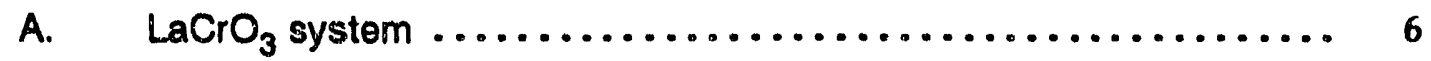

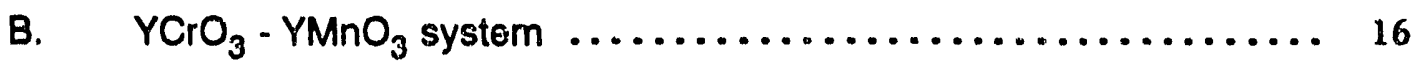

C. $\mathrm{YCrO}_{3}-\mathrm{YMnO}_{3}-\mathrm{YCoO}_{3}$ system .................... 19

III. Thermal Expansion Coefficient $\ldots \ldots \ldots \ldots \ldots \ldots \ldots \ldots \ldots \ldots \ldots \ldots$

A. $\quad \mathrm{LaCrO}_{3}-\mathrm{LaCOO}_{3}$ system $\ldots \ldots \ldots \ldots \ldots \ldots \ldots \ldots \ldots \ldots \ldots \ldots . \ldots \ldots$

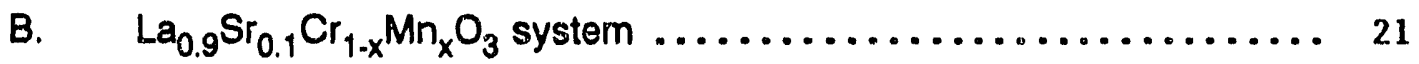

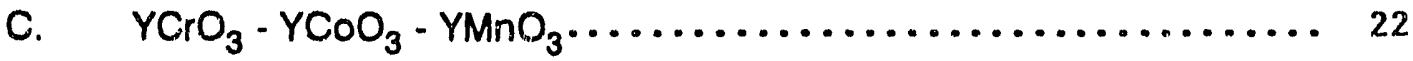

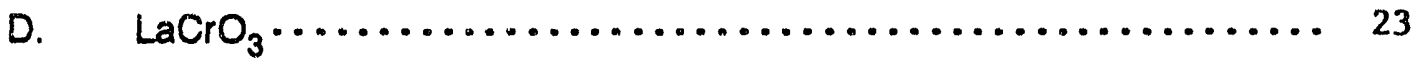

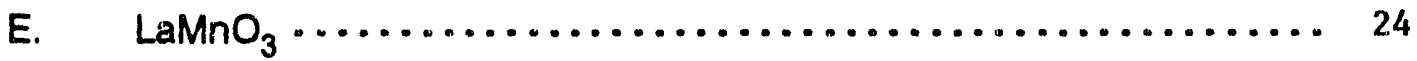

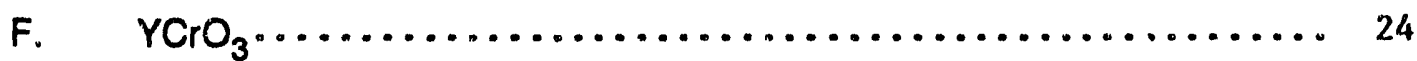

IV. Films of $\mathrm{La}_{7} \mathrm{Ca}_{3} \mathrm{Cr}_{1-x} \mathrm{Co}_{x} \mathrm{O}_{3}$ on stabilized $\mathrm{ZrO}_{2}$ substrates $\ldots \ldots \ldots \ldots \ldots .24$

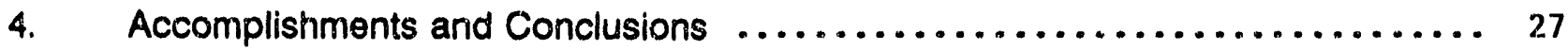

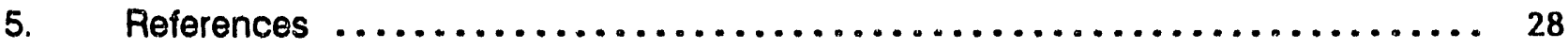

6. Contributor to Program $\ldots \ldots \ldots \ldots \ldots \ldots \ldots \ldots \ldots \ldots \ldots \ldots \ldots \ldots \ldots \ldots \ldots \ldots$

7. Manuscripts Published cr Presented ......................... 30 


\section{Introduction}

\section{Background Statements}

The purpose of this project is to develop an improved cathode for high temperature fuel cells than is currently being employed.

This project is based on the need for a more stable and reliable cathode than is currently being employed in high temperature solid oxide fuel cells (SOFC). The inability of the $\mathrm{LaMnO}_{3}$ based cathodes to withstand exposure to fuel gas without degrading their performance is one of the foremost problems confronting the successful commercialization of SOFC's.

As part of our DOE-BES program we have been investigating a number of conducting perovskite systems. Recent results indicate that some of the compositions in these systems possess electrical conductivity and stability towards reduction superior to the currently used SOFC cathode, $\mathrm{La}_{.8} \mathrm{Sr}_{.2} \mathrm{MnO}_{3}$. These results are very encouraging and suggest that we have the ability to develop an improved cathode for SOFC's. In this program we are expanding our DOE-BES studies with the intent of developing a composition which will out-perform $\mathrm{La}_{.8} \mathrm{Sr}_{.2} \mathrm{MnO}_{3}$ as a SOFC cathode.

In our DOE-BES program we have shown that the system $\mathrm{La}_{1-x} \mathrm{Ca}_{x} \mathrm{Cr}_{1-y} \mathrm{Co}_{y} \mathrm{O}_{3}(x=$ $0.1-0.3$ and $y=0.1-1.0$ ) can be sintered to densities $>95 \%$ TD in air at $1400^{\circ} \mathrm{C}$ and below. The electrical conductivity (d.c.) measurements were made as a function of temperature and in the oxygen activity range from 1 to $10^{-19}$ atm. Details of the Apparatus and experimental setup are explained elsewhere. (1) At $100{ }^{\circ} \mathrm{C}$ and $1 \mathrm{~atm}$. the conductivity ranges from $17 \mathrm{~S} / \mathrm{cm}$ to $58 \mathrm{~S} / \mathrm{cm}$ for $\mathrm{La}_{.9} \mathrm{Ca}_{1 .} \mathrm{Cr}_{.9} \mathrm{Co}_{.9} \mathrm{O}_{3}$ and $\mathrm{La}_{.7} \mathrm{Ca}_{.3} \mathrm{Cr}_{.8} \mathrm{Co}_{.2} \mathrm{O}_{3}$, respectively. Stability studies were done by quenching powder samples from $1000^{\circ} \mathrm{C}$ and $10^{-19} \mathrm{~atm}$. and subjecting quenched powders to $X$-ray diffraction. X-ray diffraction patterns of reduced samples for $y=0.1,0.2$ and 0.3 showed no second phase indicating that these compositions are structurally stable throughout the entire temperature and oxygen activity range studied.

The observed results on sintering, electrical conductivity and stability towards reduction demonstrate that $\mathrm{LaCrO}_{3}$ can be sintered in air at $1400^{\circ} \mathrm{C}$ and below with varying the composition without the deterioration of either the electrical conductivity nor high ternperature stability of the resulting dense ceramics. 


\section{Project Description}

The past DOE sponsored program has permitted the principal investigators to acquire valuable information regarding the stability of perovskite type structures towards oxidation and reduction at elevated temperatures. Through these studies a substantial base of knowledge and research capabilities was established, thus tailored materials with the desired properties can be developed. The principal investigators are using this unique background as the basis to address the problem of:

- development of a cathode material which is more stable towards reduction than the state-of-the-art Sr-doped $\mathrm{LaMnO}_{3}$ that is currently used.

- development of a cathode material which has higher electrical conductivity than $\mathrm{Sr}$ doped $\mathrm{LaMinO}_{3}$, i.e. $>100 \mathrm{~S} / \mathrm{cm}$ at $1000^{\circ} \mathrm{C}$.

The systems targeted for this study are: $(\mathrm{La}, \mathrm{Ca})(\mathrm{Cr}, \mathrm{Co}) \mathrm{O}_{3}$ and $(\mathrm{Y}, \mathrm{Ca})(\mathrm{Cr}, \mathrm{Mn}, \mathrm{Co}) \mathrm{O}_{3}$. These systems were chosen because of our previous knowledge and the fact that substantial mutual solubility exists for both systems. A series of compositions in the $\mathrm{LaCrO}_{3}-\mathrm{LaCOO}_{3}$ $\mathrm{CaO}, \mathrm{CaO}-\mathrm{LaMnO}_{3}, \mathrm{YCrO}_{3}-\mathrm{YMnO}_{3}-\mathrm{YCOO}_{3}-\mathrm{CaO}$, and $\mathrm{CaO}-\mathrm{YMnO}_{3}$ systems were synthesized using the organometallic preparation technique. ${ }^{(2)}$ The resulting powders were milled and subjected to X-ray diffraction to ensure that they were single phase. For the electrical conductivity and sintering studies the powders were pressed into bars with the aid of polyvinyl alcohol and water binder. A compaction pressure of $1500-2500 \mathrm{~kg} / \mathrm{cm}^{2}$ yielded $0.6 \times 0.4 \times 3.0 \mathrm{~cm}^{3}$ bars with green density of about $45-52 \%$ of theoretical. Densification was carried out over the temperature range 1100 to $1500^{\circ} \mathrm{C}$ for 2 to 10 hours in a SiC heated furnace. Bulk densities were measured by the liquid (Freon) displacement technique. Scanning electron micrographs of the polished and thermally etched surfaces of sintered specimens were taken using a JEOL JSM-35 CF scanning electron microscope.

Electrical conductivity and thermoelectric power measurements were made simultaneously in an apparatus which could measure three samples at a time. For these measurements the samples were cut into bars with the dimensions $\left(0.3 \times 0.3 \times 2.0 \mathrm{~cm}^{3}\right)$ and electroded with Pt paste. The specimens were mounted between two platinum blocks, which had Pt-10\% Rh/Pt thermocouples as electrical contacts, Pt wire heater was welded on the lower end of the holder to generate the temperature gradient along the vertical direction. Three sets of specimens and holders were contained in $\mathrm{Al}_{2} \mathrm{O}_{3}$ tubes within a $\mathrm{MoSi}_{2}$ furnace, where the temperature was controlled by a Eurotherm temperature controller. The oxygen activity over the samples was controlled by using flowing gas mixtures of either $\mathrm{O}_{2}-\mathrm{N}_{2}$ or $\mathrm{CO}_{2}$-forming gas $\left(1 \mathrm{OH}_{2}-9 \mathrm{ON}_{2}\right)$. A stabilized zirconia oxygen sersor was used to monitor the 
oxygen partial pressure of the gas mixture. The Seebeck coefficients were determined by measuring temperature gradients and thermal emf's through the common leads of the thermocouples. Electrical conductivity measurements were made using the two-probe, four. wire Kelvin technique in which two leads carry the test signal (1mA) and the other two measure the voltage drop. The measurements were made using a data logger (a Hewlett Packard 3497A data acquisition/control unit), which employs a HP-85 computer both as a control and readout device. Thermal expansion measurements were made on an Orton dilatometer over the tempe:ature range 25 to $1000^{\circ} \mathrm{C}$.

\section{Results and Discussion}

\section{Sintering Studies}

The primary difficulty of sintering $\mathrm{LaCrO}_{3}$ and $\mathrm{YCrO}_{3}$ based perovskites in air arises from the volatilization of $\mathrm{Cr}$ from the structure at temperatures in excess of $1400^{\circ} \mathrm{C}$, resulting in porosity. This is inhibited by using reducing atmospheres during sintering, with oxygen activities of $10^{-10}-10^{-12}$ at $1700^{\circ} \mathrm{C}$. ${ }^{(2)}$ Meadowcroft ${ }^{(4)}$ showed that the sintered density of $\mathrm{La}_{.84} \mathrm{Sr}_{.16} \mathrm{CrO}_{3}$ increased when excess $\mathrm{Sr}$ was added in the form of $\mathrm{SrCO}_{3}$ before sintering. The maximum beneficial effect observed was a sharp increase in sintered density when $4 \mathrm{~m} \%$ $\mathrm{SrCO}_{3}$ was added. This was probably due to the formation of $\mathrm{SrCrO}_{4}$ at intermediate temperatures followed by melting and liquid-phase sintering. Flandermeyer et.al. ${ }^{(4)}$ used low melting oxide eutectics as well as La, $\mathrm{Y}$ and Mg fluorides up to 8-10 wt\% to increase the density of sintered compacts, however, these fluxes are not desirable in the SOFC environment $\left(1000^{\circ} \mathrm{C}\right)$. In this study, we have incorporated various dopants, on both La and $\mathrm{Cr}$ sites of the $\mathrm{LaCrO}_{3}$ and $\mathrm{YCrO}_{3}$ compounds, to enhance the sinterability in air. These dopants, $\mathrm{Ca}$ and $\mathrm{Co}$, are expected to generate a transient liquid to aid sinterability in air at temperatures below $1400^{\circ} \mathrm{C}$.

\section{A. $\quad(\mathrm{La}, \mathrm{Ca})(\mathrm{Cr}, \mathrm{CO}) \mathrm{O}_{3}$ System}

In the case of $\mathrm{LaCrO}_{3}$, neither $\mathrm{Ca}$ nor $\mathrm{Co}$ additions by themselves enhanced sinterability when added at levels of less than $30 \mathrm{~m} \%$ (see Table I).

These results show that the substitution of $\mathrm{Co}$ for $\mathrm{Cr}$ in $\mathrm{LaCrO}_{3}$ improved the sinterability. Significant improvement in densification was observed with substitution of 20 $\mathrm{m} \% \mathrm{Co}$ for $\mathrm{Cr}$, and $95 \%$ theoretical density was achieved in air at $1500^{\circ} \mathrm{C}$ with substitution of $50 \mathrm{~m} \% \mathrm{Co}$ for $\mathrm{Cr}$. However, substitution of $\mathrm{Ca}$ for $\mathrm{La}$ in $\mathrm{LaCrO}_{3}$ did not improve the 
sintirability, but in $\mathrm{LaCoO}_{3}$ sinterability was improved and the melting temperature was reduced. The Co substitution for $\mathrm{Cr}$ in $\mathrm{LaCrO}_{3}$ apparently forms a hitherto unidentified trarisient liquid in air at temperatures below $1500^{\circ} \mathrm{C}$, thereby improving sinterability. However, when both $\mathrm{Ca}$ and $\mathrm{Co}$ are added simultaneously, sintering occurred at temperatures below $1450^{\circ} \mathrm{C}$ (see Table II).

Table I. Sintered Density and Percent Theoretical Density as a Function of Co knd Temperature. (Sintering Time 2 hrs.)

$\mathrm{LaCr}_{1-y} \mathrm{Co}_{y} \mathrm{O}_{3}$
Compossition

(y)

$y=0.0$

$y=0.1$

$y=0.2$

$y=0.5$

$y=0.7$

$y=1.0$
1100

Density \%TD $\frac{g / c c}{4.0660}$

4.3264

4.8070

$5.05 \quad 72$

5.1573

5.8882

\section{0}

Temperature $\left({ }^{\circ} \mathrm{C}\right)$

1300

1400

Density \%TD

$\frac{\mathrm{g} / \mathrm{cc}}{4.1061}$

4.4165

5.5081

$6.08 \quad 87$

$6.21 \quad 88$

6.4295
1500

Density \%TD

g/cc

4.1161

4.6268

5.7385

6.6395

MELTED

MELTED

Table II. Sintered Density and Percent Theoretical Density as a Function of Ca and Temperature. (Sintering Time 2 hrs.)

$$
\begin{aligned}
& \mathrm{La}_{1-\mathrm{x}} \mathrm{Ca}_{2} \mathrm{Cr}_{0.9} \mathrm{Co}_{0.1} \mathrm{O}_{3} \\
& \text { Composition } \\
& \text { (x) }
\end{aligned}
$$

1100

Density \%TD $\mathrm{g} / \mathrm{cc}$

$4.32 \quad 64$

$4.52 \quad 68$

4.8274

$5.34 \quad 83$

$3.80 \quad 62$

$5.66 \quad 89$
1200 Density \%TD Density \%TD gice

$4.33 \quad 64$

4.6070

$5.13 \quad 79$

$5.74 \quad 89$
3.87

$3.87 \quad 62$

$6.09 \quad 95$

$\mathrm{g} / \mathrm{cc}$

$4.35 \quad 64$

$5.37 \quad 81$

5.8790

$5.96 \quad 93$

$3.90 \quad 63$

MELTED
Temperature $\left({ }^{\circ} \mathrm{C}\right)$

$1300 \quad 1400 \quad 1500$
gicc

$4.41 \quad 65$

$5.92 \quad 90$

4.6268

6.1194

5.3496

$6.09 \quad 95$

6.2296

$3.92 \quad 63$

$6.10 \quad 95$

The enhancement of sintering is due to the formation of $\mathrm{a} \mathrm{CaO} / \mathrm{CoO}$ liquid phase at temperatures below $1300^{\circ} \mathrm{C}$. Figure 1 is a SEM photomicrograph of a polished surface from a specimen of composition $\mathrm{La}_{8} \mathrm{Ca}_{2} \mathrm{Cr}_{.8} \mathrm{Co}_{2} \mathrm{O}_{3}$ which was sintered for only ten minutes at $1200^{\circ} \mathrm{C}$ and quenched. As can be seen much liquid (glassy-like phase) was present. 
In summary, we were sucesstul in developing $\mathrm{La}_{1-x} \mathrm{Ca}_{x} \mathrm{Cr}_{1-y} \mathrm{Co}_{y} \mathrm{O}_{3}$ cornpositions that sintered at temperatures below $1400^{\circ} \mathrm{C}$ in air with the aid of liquid phase. The composition of the liquid phase was dependent upon the ame!snt of $\mathrm{Co}$ and $\mathrm{Ca}$ substituticn. The liquid phase dispersed along the grain boundaries and did not alter the electrical conductivity and stability of the materials if the Co substitution for $\mathrm{Cr}$ was kept lower than $30 \mathrm{~m} \%$; otherwise, the stability against reduction at high temperature was diminished.

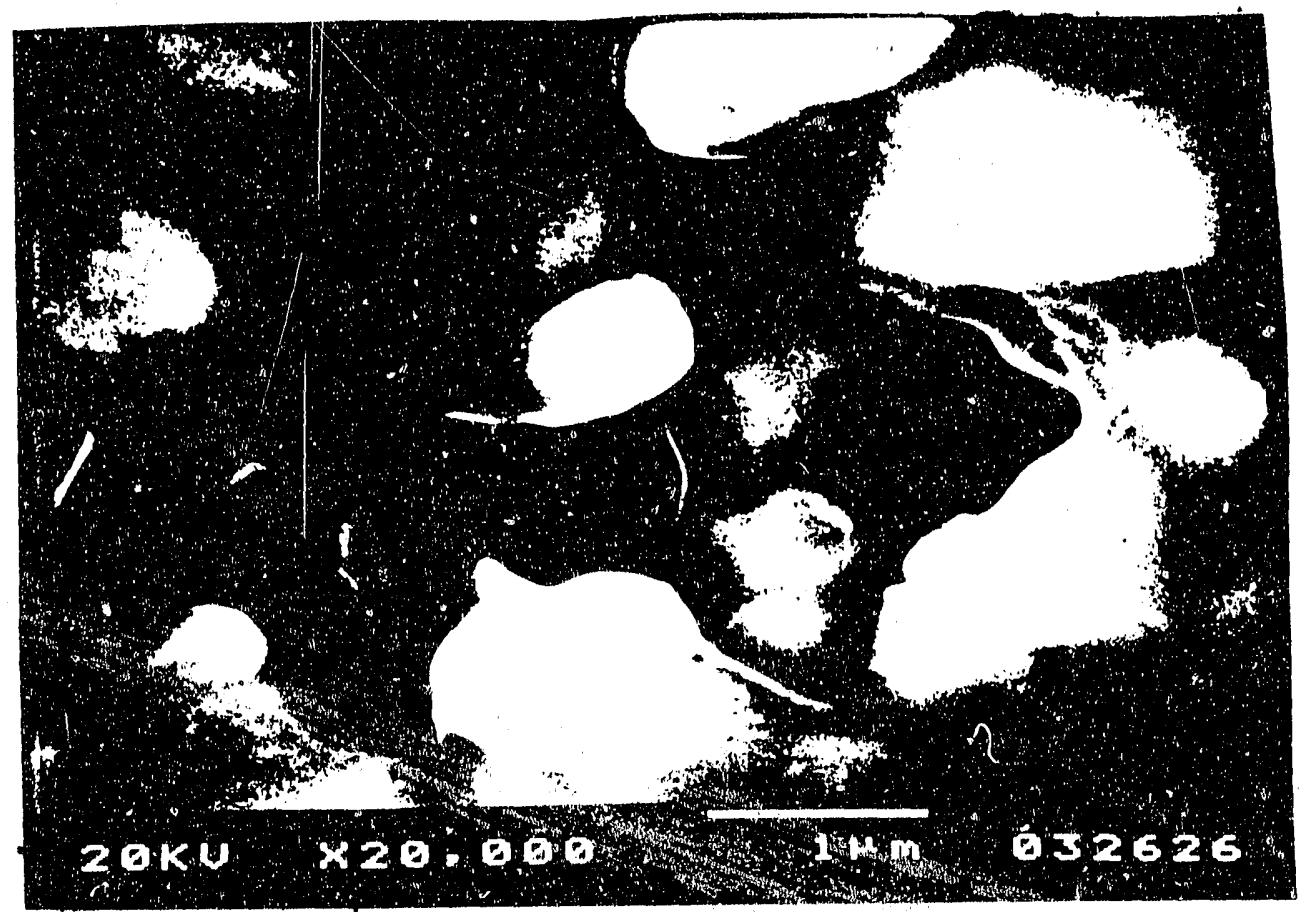

Figure 1: $\quad$ La ${ }_{.8} \mathrm{Ca}_{.2} \mathrm{Cr}_{.8} \mathrm{Co}_{2} \mathrm{O}_{3}$ heated at $1200^{\circ} \mathrm{C}$ for $10 \mathrm{Min}$. and wais? quenched to roomi temperature

\section{B. $\quad(Y, \mathrm{Ca})(\mathrm{Cr}, \mathrm{Mn}, \mathrm{Co}) \mathrm{O}_{3}$ System}

Calcium is soluble in $\mathrm{YCrO}_{3}$ uf to $20 \mathrm{~m} \%$ with no change in the orthorhombic crystal structure.

$\mathrm{Y}_{1-x} \mathrm{Ca}_{x} \mathrm{CrO}_{3}$ is difficult to densify. It requires temperatures of $1750^{\circ} \mathrm{C}$ and oxygen activity of less than $10^{-9}$ atm similar to $\mathrm{LaCrO}_{3}$. However, these compositions are found to be stable towards reduction in $\mathrm{H}_{2}$ at temperatures to $1500^{\circ} \mathrm{C} . \mathrm{Y}_{1-x} \mathrm{Ca}_{x} \mathrm{MnO}_{3}$ has a miscibility gap for $10 \mathrm{~m} \%<\mathrm{Ca}<40 \mathrm{~m} \%$ (see Table III). For Ca $<10 \mathrm{~m} \%$, the crystal structure is hexagonal and for $\mathrm{Ca}>40 \mathrm{~m} \%$ it becomes orthorhombic. Pure $\mathrm{YMnO}_{3}$ is difficult to densify, however, compositions containing more than $30 \mathrm{~m} \% \mathrm{Ca}$ densify well at $1400^{\circ} \mathrm{C}$. 
Table III. Conductivity and TEC of $\mathrm{Y}_{1-x} \mathrm{Ca}_{x} \mathrm{MnO}_{3}$ as a function of $\mathrm{Ca}$ content

\begin{tabular}{ccll}
\hline Ca Content & TEC $\left(500-1000^{\circ} \mathrm{C}\right)$ & $\underline{\sigma\left(900^{\circ} \mathrm{C}\right)}$ & Structuig \\
\cline { 2 - 4 } $0 \mathrm{~m} \%$ & $11.5 \times 10^{-6} \mathrm{C}^{-1}$ & $0.2 \mathrm{~S} / \mathrm{cm}$ & Hex \\
10 & 10.0 & 13 & Hex/Ortho \\
20 & 9.7 & 52 & Hex/Ortho \\
30 & 9.7 & 85 & Hex/Ortho \\
40 & 10.1 & 133 & Ortho \\
50 & 8.5 & 190 & Ortho \\
\hline
\end{tabular}

In an effort to densify $\mathrm{YCrO}_{j}$ in air we have tried the same procedure used for $\mathrm{LaCrO}_{3}$. That is, the simultaneous substitution of $\mathrm{Ca}$ and $\mathrm{Co}$. Our initial results indicate that this system can be densified in air at temperatures below $1500^{\circ} \mathrm{C}$. Summary of our results was presentec at the 1990 Fuel Cell Seminar in Phoenix, AZ in November 1990.

\section{Electrical Conductivity Studies}

\section{A. $\quad \mathrm{LaCrO}_{3}$ System}

D.C. electrical conductivity measurements were made for compositions in air over a temperature range from 20 to $1200^{\circ} \mathrm{C}$. Previous studies on $(\mathrm{La}, \mathrm{Ca}, \mathrm{Sr}) \mathrm{CrO}_{3}{ }^{(6,7)}$ and $(\mathrm{La}, \mathrm{Ca}, \mathrm{Sr}) \mathrm{CoO}_{3}{ }^{(8-13)}$ show both systems to be p-type conductors with holes moving through the structure oy the small polaron mechanism.

The electrical conductivity for small polarons takes the form:

$$
\sigma=(C / T) \exp (-E / k T)
$$

where $C$ is both a charge carrier concentration and material constant, $T$ is the absolute temperature, $E$ is activation energy and $k$ is Boltzman's constant. Therefore, for materials which obey the small polaron mechanism, a plot of $\log (\sigma T)$ versus $1 / T$ gives a straight line whose slope is proportional to the activation energy. Charge is transferred when the polaron hops from one cation to another. The electrical conductivity is often enhanced by substituting a lower valence ion (acceptor) such as $\mathrm{Ca}$ for La.

The electrical conductivity data for $\mathrm{La}_{1-x} \mathrm{Ca}_{x} \mathrm{Cr}_{0.9} \mathrm{Co}_{0.1} \mathrm{O}_{3}, \mathrm{La}_{1-x} \mathrm{Ca}_{x} \mathrm{Cr}_{0.8} \mathrm{Co}_{0.2} \mathrm{O}_{3}$ and $\mathrm{La}_{1-\mathrm{x}} \mathrm{Ca}_{\mathrm{x}} \mathrm{Cr}_{0.7} \mathrm{Co}_{0.3} \mathrm{O}_{3}$ (with $\mathrm{x}=0.1,0.2$ and 0.3 ) are shown in figures 2,3 , and 4 , respectively, as $\log (\sigma)$ versus reciprocal temperature. When plotted as $\log$ oT versus reciprocal temperature, the plots are linear suggesting that the small polaron mechansim is obeyed. For a given $\mathrm{Ca}$ content, the activation energies were independent of Co concentration, the 
approximate values were $0.45,0.2,0.2$ and 0.2 ev for Ca contents of $0,10,20$ and 20 mole \% respectively.

Previous studies on $(\mathrm{La}, \mathrm{Ca}) \mathrm{CrO}_{3}{ }^{(7)}$ and $(\mathrm{La}, \mathrm{Ca}) \mathrm{CoO}_{3}{ }^{(8)}$ have shown that they have intrinsic p-type conductivity due to the formation of cation vacancies. The electrical conductivity in these oxides is enhanced by substituting $\mathrm{Ca}^{2+}$ for $\mathrm{La}^{3+}$, which is compensated by a $\mathrm{Cr}^{3+} \rightarrow \mathrm{Cr}^{4+}$ transition. This can be represented, for $\mathrm{Ca}$ doped $\mathrm{LaCrO}_{3}$ by:

$$
\mathrm{La}_{1-x}{ }^{3+} \mathrm{Ca}_{x}^{2+} \mathrm{Cr}_{1-x}{ }^{3+} \mathrm{Cr}_{x}{ }^{4+} \mathrm{O}_{3}
$$

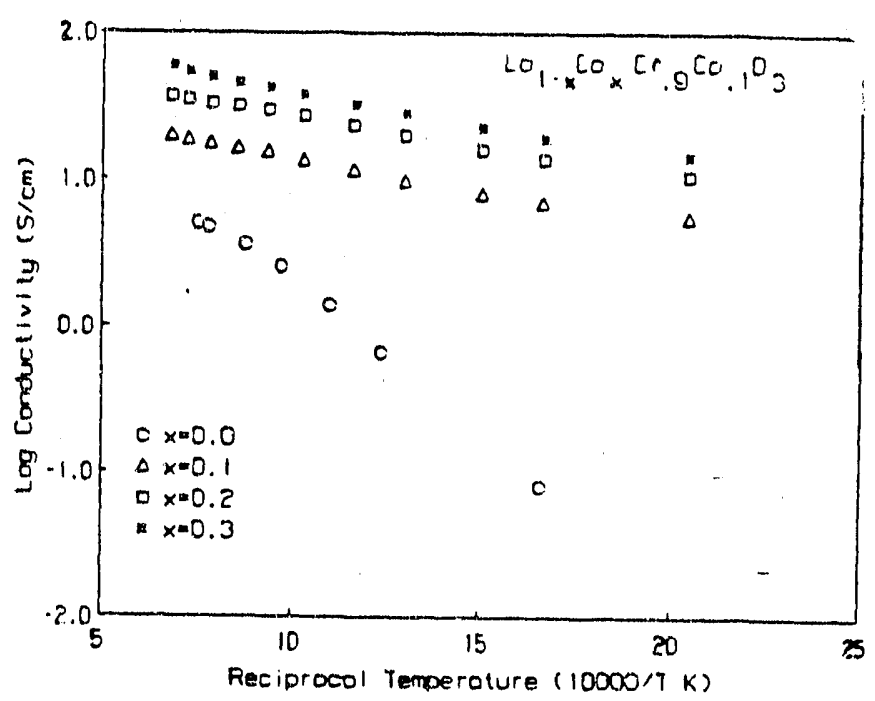

Figure 2: Electrical conductivity of $\mathrm{La}_{1-x} \mathrm{Ca}_{x} \mathrm{Cr}_{.9} \mathrm{Co}_{.1} \mathrm{O}_{3}$ as a function of Ca content and temperature

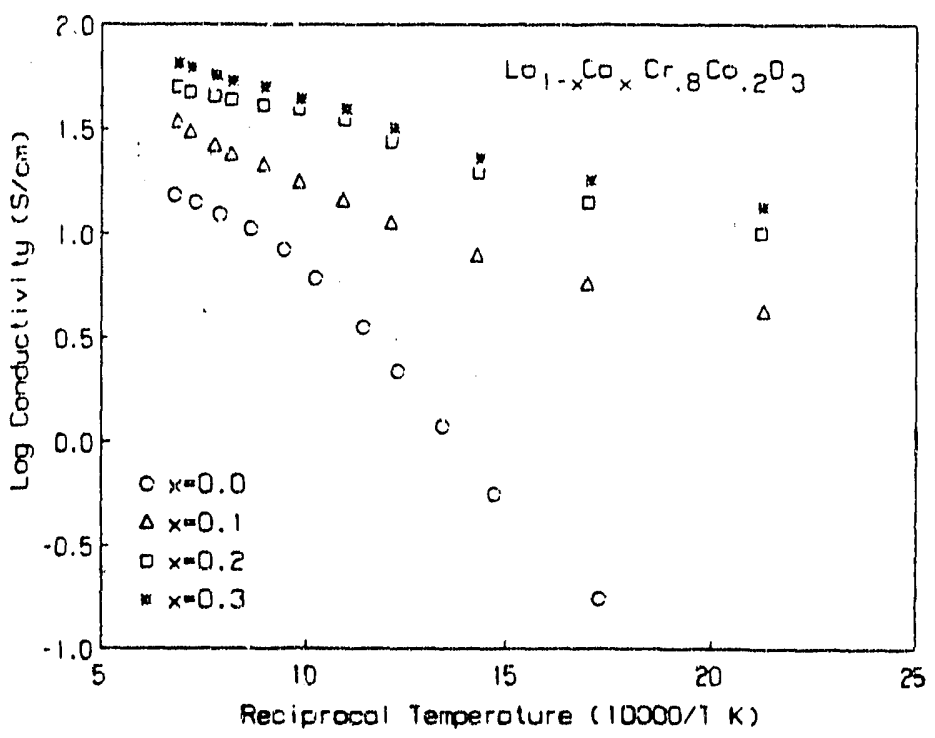

Figure 3: Electrical conductivity of $\mathrm{La}_{1-x} \mathrm{Ca}_{x} \mathrm{Cr}_{.8} \mathrm{Co}_{.2} \mathrm{O}_{3}$ as a function of $\mathrm{Ca}$ content and temperature 


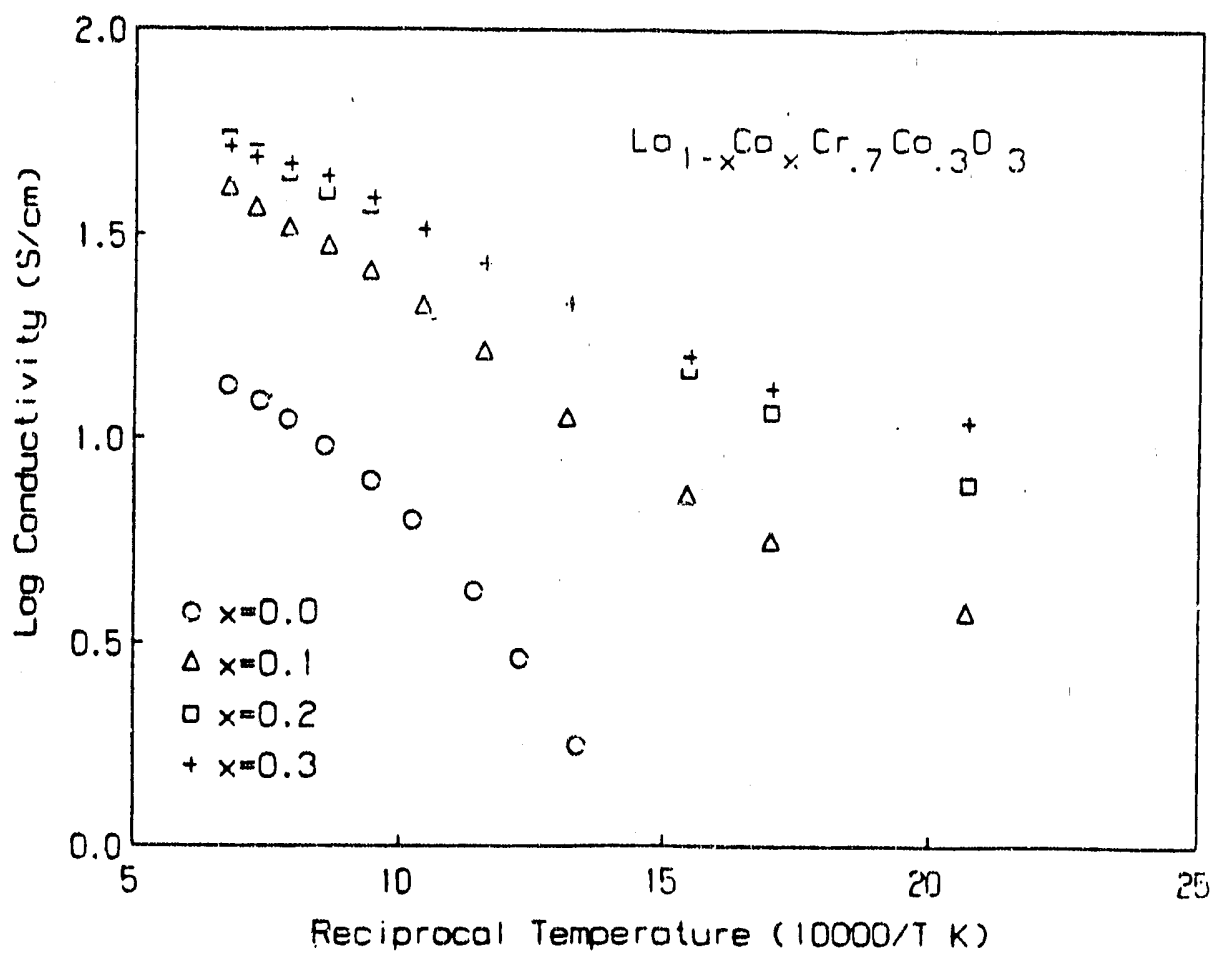

Figure 4: Electrical conductivity of $\mathrm{La}_{1-x} \mathrm{Ca}_{x} \mathrm{Cr}_{.7} \mathrm{Co}_{.3} \mathrm{O}_{3}$ as anction of $\mathrm{Ca}$ content and teinperature

It is believed that the $\mathrm{Cr}^{3+} \mathrm{d}$ states with $\mathrm{t}_{2 g}$ symmetry have small overlap integrals resulting in narrow bands and a tendericy toward localization, whereas $d$ states with $e_{g}$ symmetry have a larger overlap, due to hybridization with oxygen levels, and form a wider band of itinerant states higher in energy and not wecupled in the ground state of the system. All levels associated with the $A$ sublattice atoms are well atsove or below the Fermi energy, and their prirnary role is to determine the occupancy of the $\mathrm{t}_{2 g} \mathrm{Cr}$ states through charge compensation. ${ }^{(6)}$ Substitution of Ca for La will create a hole in the $\mathrm{Cr} \mathrm{t}_{2 \mathrm{~g}}$ band and lead to an increase in the electrical conductivity.

As for $\mathrm{Sr}$ and $\mathrm{Ba}$ substitutions in $\mathrm{LaCoO}_{3},(10,11)$ electrical neutrality of solid solutions of $\mathrm{La}_{1-x} \mathrm{Ca}_{x} \mathrm{CoO}_{3}$ can be achieved either via the formation of $\mathrm{Co}^{4+}$ or by oxygen vacancies, $\mathrm{V}_{0}$, or both, following the equation:

$$
\mathrm{La}_{1-x}{ }^{3+} \mathrm{Ca}_{x}{ }^{2+} \mathrm{Co}^{3+}{ }_{1-x+2 y}=0^{4+}{ }_{x-2 y} \mathrm{O}^{2-}{ }_{3-y}\left(\mathrm{~N}_{0}\right)_{y} \text {. }
$$

The substitution of $\mathrm{La}^{3+}$ by $\mathrm{Ca}^{2+}$ in $\mathrm{LaCoO}_{3}$ leads to an increase in the electrical conductivity and to a transformation from semiconductive to metallic conductivity. (12) No contribution to the electronic conductivity is anticipated if the substitution of $\mathrm{La}^{3+}$ by $\mathrm{Ca}^{2+}$ is compensated by the pormation of oxygen vacancies.

As in the case of $\mathrm{La}_{1-x} \mathrm{Ca}_{x} \mathrm{CrO}_{3}$ and $\mathrm{La}_{1-x} \mathrm{Ca}_{x} \mathrm{CoO}_{3}$, the substitution of $\mathrm{Ca}$ for $\mathrm{La}$ in $\mathrm{La}_{1-x} \mathrm{Ca}_{x} \mathrm{Cr}_{1-y} \mathrm{Co}_{y} \mathrm{O}_{3}$, should result in the formation of $\mathrm{Cr}^{4+}$ and $\mathrm{Co}^{4+}$ in order to preserve the electrical neutrality. Figure 5 shows the electrical conductivity at $1000^{\circ} \mathrm{C}$ as a function of $\mathrm{Ca}$ 
content in $\mathrm{La}_{1 \times x} \mathrm{Ca}_{x} \mathrm{Cr}_{0.9} \mathrm{Co}_{0.1} \mathrm{O}_{3}$ and $\mathrm{L}_{1-x} \mathrm{Ca}_{x} \mathrm{Cr}_{0.8} \mathrm{Co}_{0.2} \mathrm{O}_{3}$. The electrical conductivity at $1000^{\circ} \mathrm{C}$ as a function of $\mathrm{Ca}$ in $\mathrm{La}_{1-x} \mathrm{Ca}_{x} \mathrm{CrO}_{3}$ is included from reference 6 for comparison and to provide a relative $y=0.0$ case. As can be seer, the electrical conductivity of $L a_{1}$. ${ }_{x} \mathrm{Ca}_{x} \mathrm{Cr}_{0.9} \mathrm{Co}_{0.1} \mathrm{O}_{3}$ and $\mathrm{La}_{1-x} \mathrm{Ca}_{x} \mathrm{Cr}_{0.3} \mathrm{Co}_{0.2} \mathrm{O}_{3}$ at $1000^{\circ} \mathrm{C}$ is slightly higher than that of $\mathrm{La}$. ${ }_{x} \mathrm{Ca}_{x} \mathrm{CrO}_{3}$. This may be due to a contribution of $\mathrm{Co}$ to the conductivity, but this is yet to be confirmed.

Seebeck measurements were made in order to determine the type and concentration of charge carriers. Figures 6-8 are the resulting Seebeck coefficients plotted as a function of temperature for $\mathrm{LaCr}_{1-y} \mathrm{Co}_{y} \mathrm{O}_{3}, \mathrm{La}_{1-x} \mathrm{Ca}_{x} \mathrm{Cr}_{0.9} \mathrm{Cc}_{0.1} \mathrm{O}_{3}$ and $\mathrm{La}_{1-x} \mathrm{Ca}_{x} \mathrm{Cr}_{0.8} \mathrm{Co}_{0.2} \mathrm{O}_{3}$, respectively. (In figure 8, the dashed line is taken from Ref. 6 for comparison.) In $\mathrm{LaCr}_{1-y} \mathrm{Co}_{y} \mathrm{O}_{3}$, the substitution of $\mathrm{Co}$ for $\mathrm{Cr}$ increases the carrier concentration.

As the Ca content increased, the Seebeck coefficients exhibited a temperature independent behavior, indicating that the carrier mobility, rather than carrier concentration, was thermally activated. According to Heikes formula this type of behavior indicates a small polaron conduction mechanism which agrees with the electrical conductivity measurements.

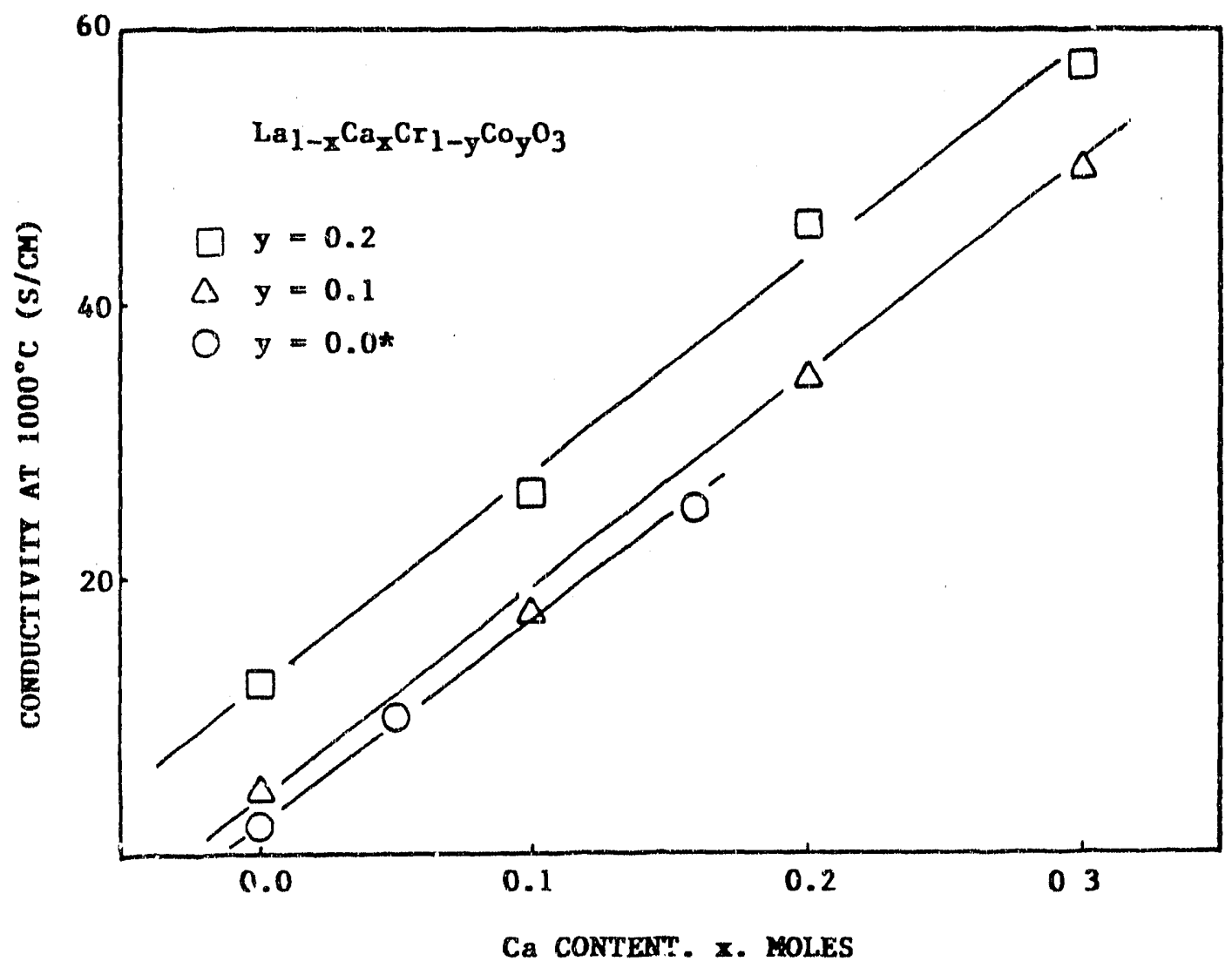

Figure 5: Electrical conductivity at $1000^{\circ} \mathrm{C}$ as a function of Ca content *S. Song, et al. $(7)$ 


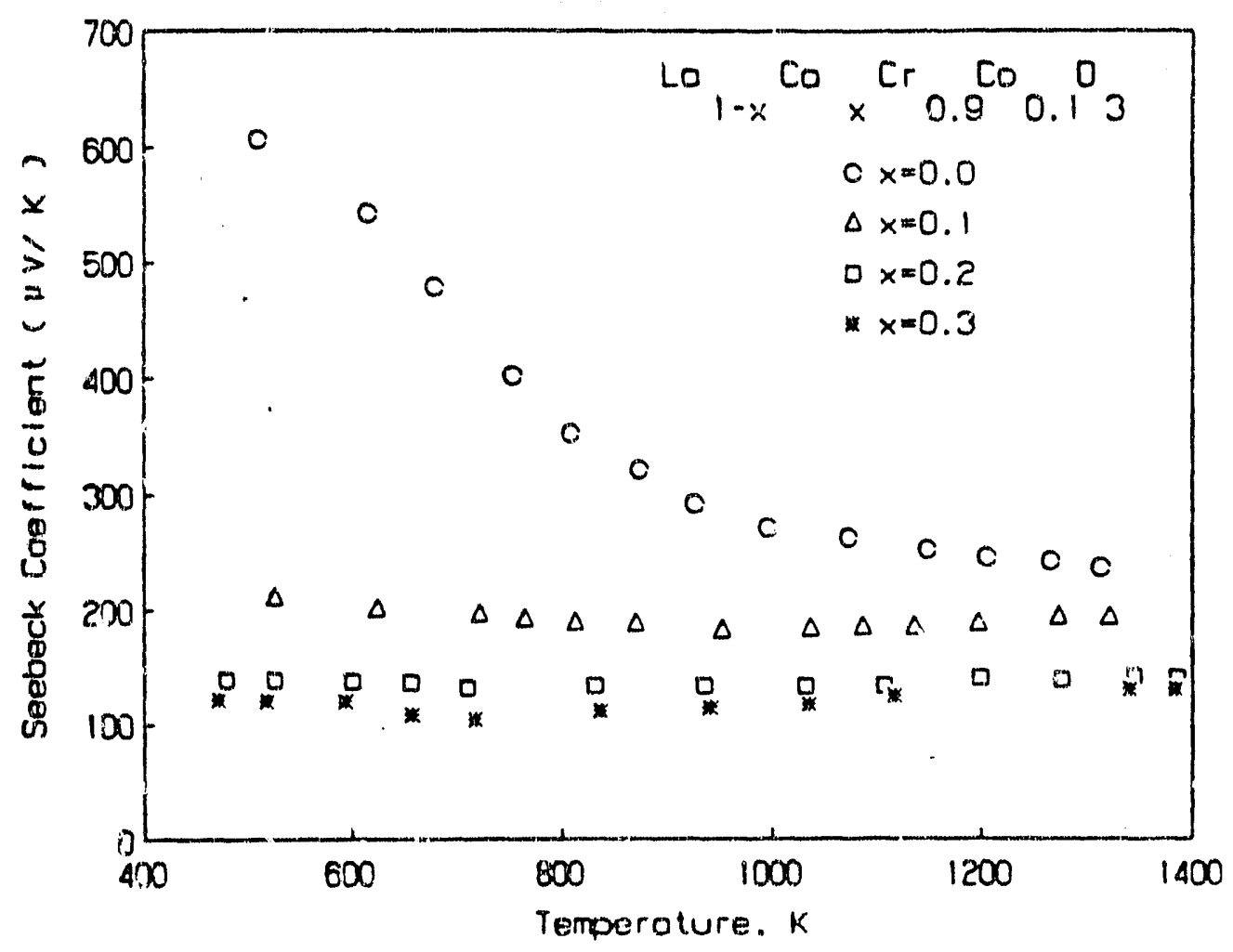

Figure 6: Seebeck coefficients of $\mathrm{LQ}_{1 \cdot \mathrm{x}} \mathrm{CQ}_{8} \mathrm{Cr}_{8} \mathrm{CO}_{, 1} \mathrm{O}_{3}$ as a function of $\mathrm{Ca}$ and temperature

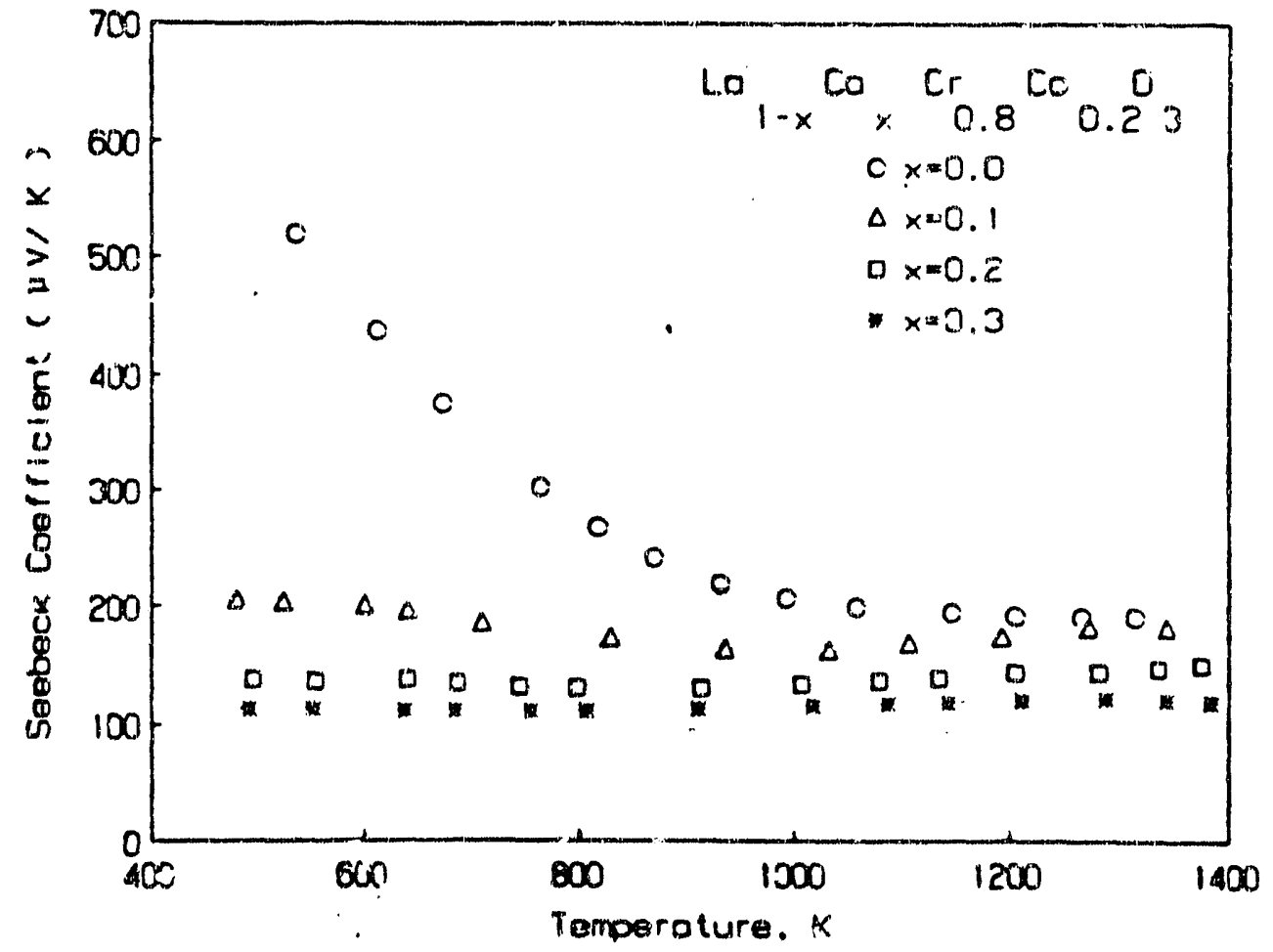

Figure 7: Seebeck coefizicients of $\mathrm{LQ}_{1-x} \mathrm{C}_{2 \times} \mathrm{Cr}_{.8} \mathrm{CO}_{.2} \mathrm{O}_{3}$ as a tunction of $\mathrm{Ca}$ and temperature 


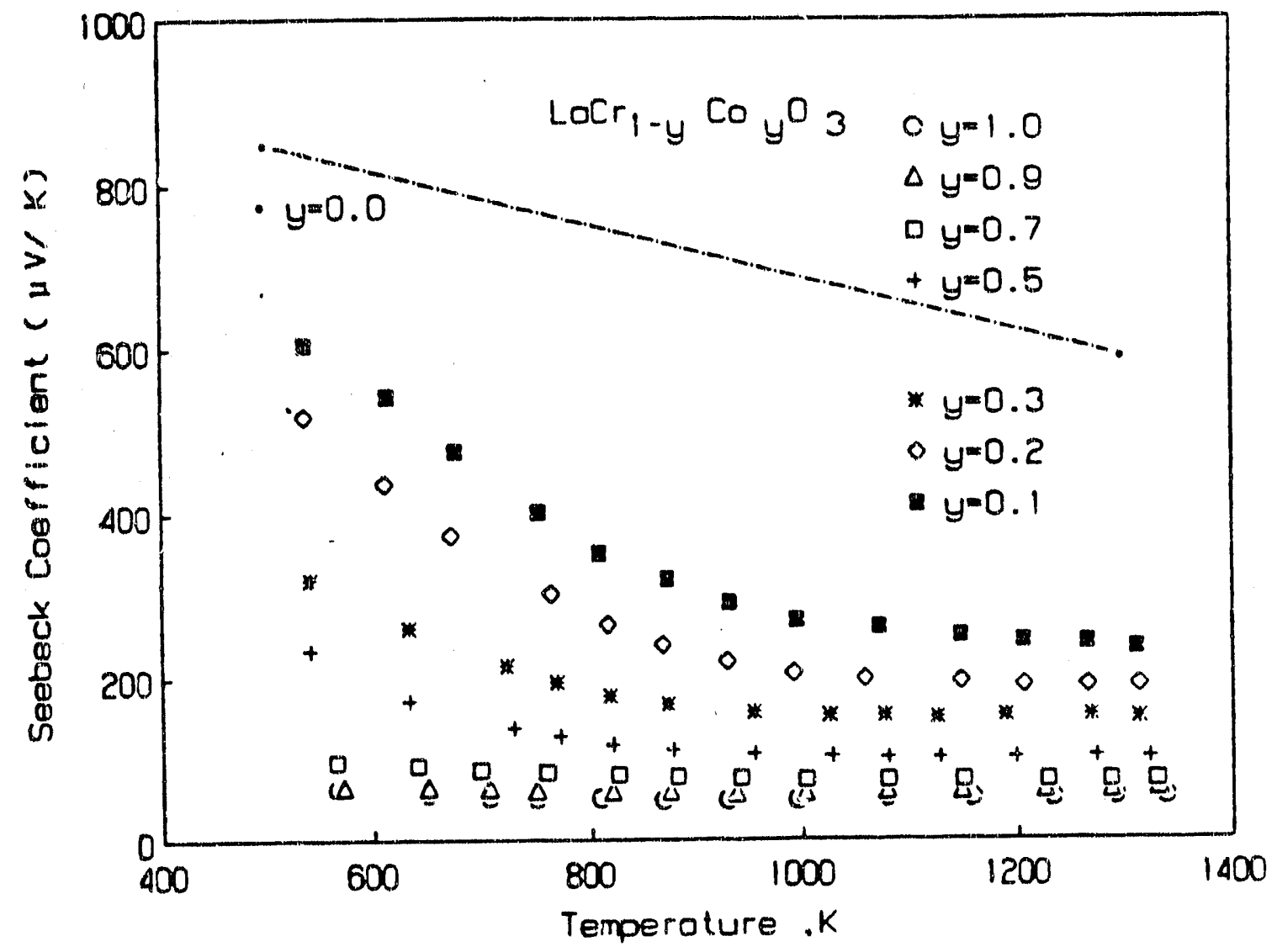

Figure 8: Seebeck coefficients of $\mathrm{LaCr}_{1-y} \mathrm{Co}_{y} \mathrm{O}_{3}$ as a function of Co content and temperature

\section{Oxygen Activity Deperidence}

The de electrical conductivity measurements for $\mathrm{La}_{1-x} \mathrm{Ca}_{x} \mathrm{Cr}_{1-y} \mathrm{Co}_{y} \mathrm{O}_{3}(x=0.1,0.2,0.3$ and $y=0.1,0.2,0.3)$ were made as a function of oxygen activity at $1000^{\circ} \mathrm{C}$. The results are shown in figures 9-10. The electrical conductivity data showed sirnilar oxidation-reduction behavior. In the high oxygen activity region, within the experimental error, the electrical conductivity was nearly constant. The conductivity decreased as a function of oxygen activity to the one quarter power as reduction progressed. The constant electrical conductivity which exists in the high oxygen activity region may be easily understood if it is assumed that the carrier concentration and electronic compensation predominate. In the low oxygen activity region, oxygen vacancies are formed and the electrical conductivity begins to decrease as a result of ionic compensation.

From defect chemistry modeling, the defect structure and electrical concuctivity changes can be predicted under various oxygen activity and temperature conditions. $A$

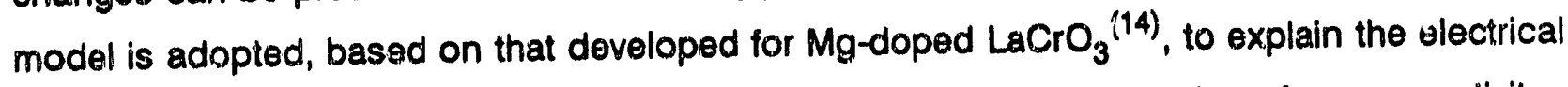
ronductivity of $\mathrm{La}_{1-x} \mathrm{Ca}_{x} \mathrm{Cr}_{1-y} \mathrm{CO}_{y} \mathrm{O}_{3}$ (where $y$ is less than 0.3) as a function of oxygen activity. In $\mathrm{La}_{1-x} \mathrm{Ca}_{x} \mathrm{Cr}_{1-y} \mathrm{Co}_{y} \mathrm{O}_{3}, \mathrm{Co}^{3+}$ substitutes for $\mathrm{Cr}^{3+}$, and $\mathrm{Ca}^{2+}$ substitutes for $\mathrm{La}^{3+}$ on normal 
lattice sites. The acceptor $\mathrm{Ca}^{2+}$ possesses one effective negative charge which can be compensated for either by $\mathrm{Cr}^{3+} \rightarrow \mathrm{Cr}^{4+}$ or $\mathrm{Co}^{3+} \rightarrow \mathrm{Co}^{4+}$ transitions or by the formation of oxygen vacancies. If such a substitution is compensated by the formation of oxygen vacancies, no contribution to the electronic conductivity is anticipated.

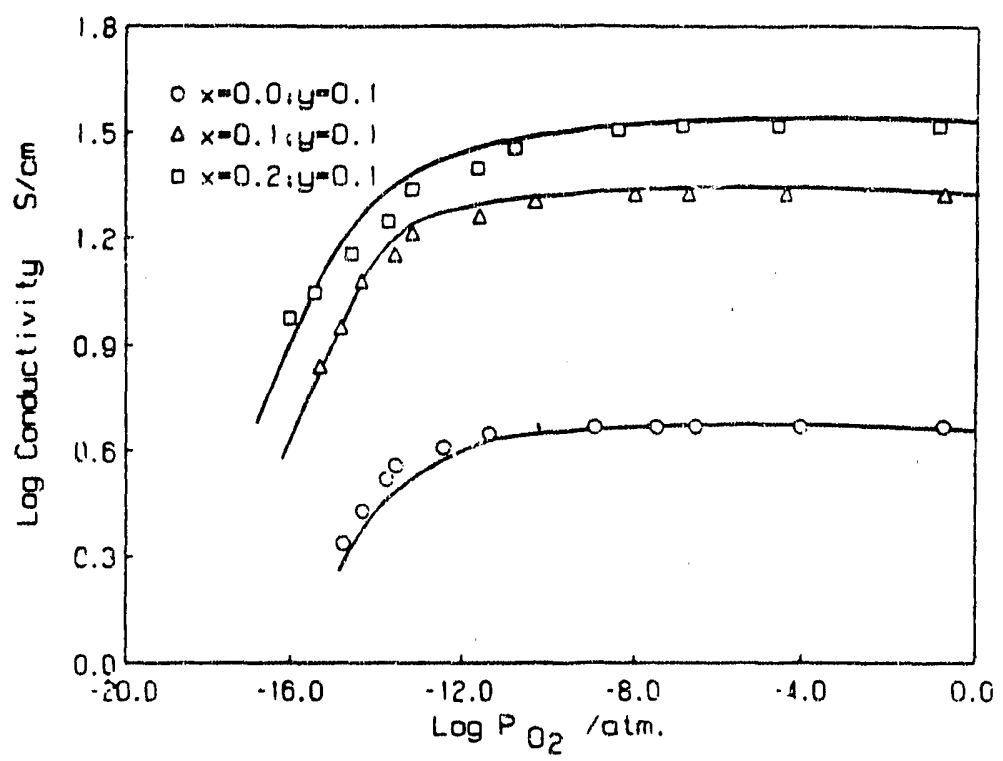

Figure 9: Log conductivity v8. log oxygen activity for $\mathrm{La}_{1-x} \mathrm{Ca}_{x} \mathrm{Cr}_{.8} \mathrm{Co}_{.7} \mathrm{Co}_{3}$ at $1000^{\circ} \mathrm{C}$ (Solld lines were derived from the model)

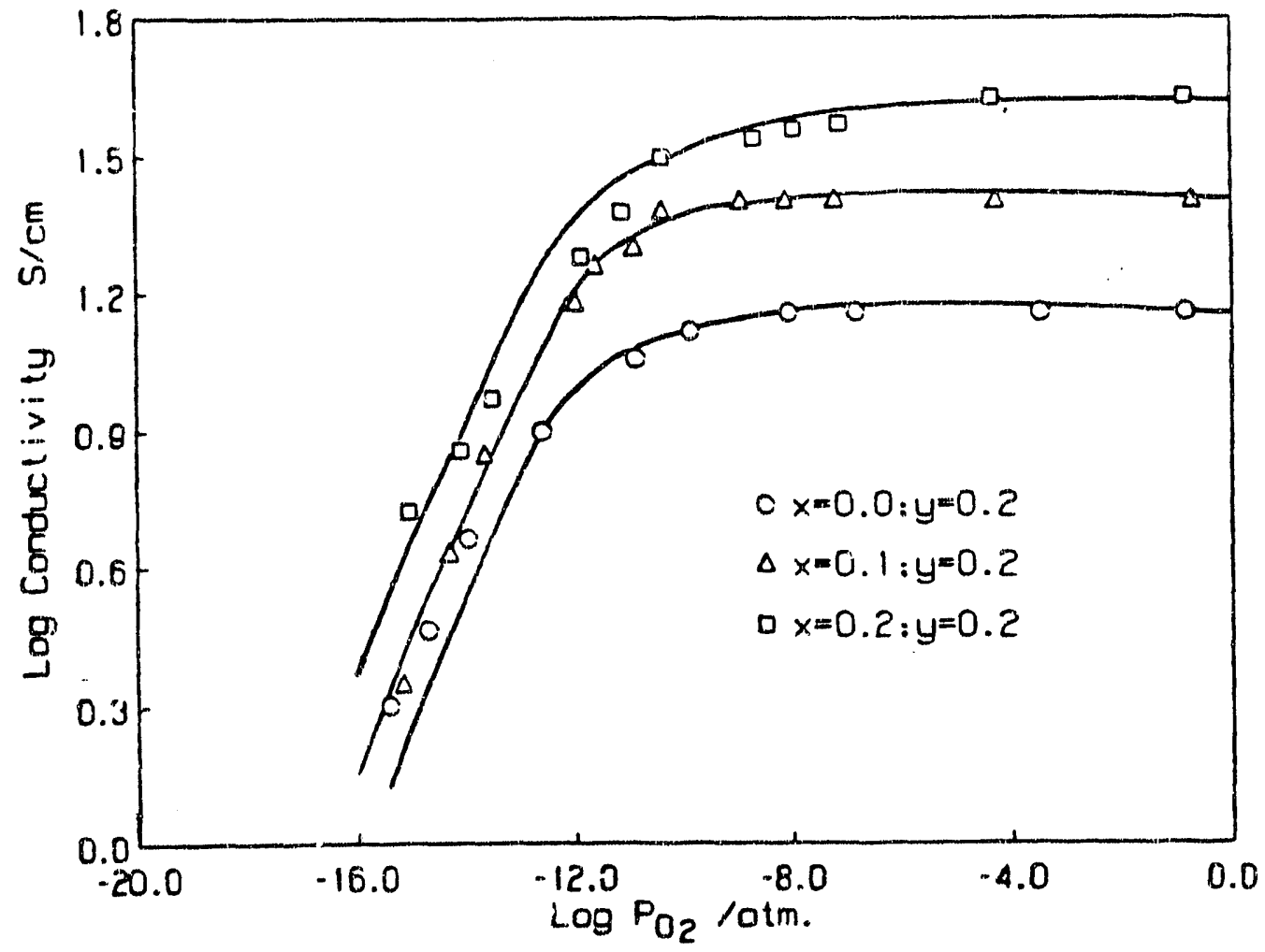

Figure 10: Log conductivity vs. $\log$ oxygen activity for $\mathrm{LS}_{1-x} \mathrm{Ca}_{x} \mathrm{Cr}_{.8} \mathrm{Co}_{2 .} \mathrm{O}_{3}$ at $1000^{\circ} \mathrm{C}$ (Solid lines were dertved from the model) 
Since, for this compound, the cations and anions are of comparable size, it can be assumed that the native defects are of the Schottky type. The Schottky reaction, using the kroger-Vink notation ${ }^{(15)}$, is expressed by

$$
\begin{aligned}
& \text { nill }=V_{L a}^{\prime \prime \prime}+V_{C r, C o}^{\prime \prime \prime}+V_{o ̈} \\
& K_{s}=\left[V_{L Q}^{\prime \prime \prime}\right]\left[V_{C r, C o}^{\prime \prime \prime}\right]\left[V_{\cdot j}\right]^{3}
\end{aligned}
$$

Since this is a closed system, tha cation stoichiometry must remain constant, therefore, [V $\left.\mathrm{V}_{\mathrm{La}}^{\prime \prime \prime}\right]$ $=\left[\mathrm{V}_{\mathrm{Cr}, \mathrm{CO}}^{\prime \prime \prime}\right]=2\left[\mathrm{~V}_{\mathrm{M}}^{\prime \prime \prime}\right]$ throughout the entire single-phase region.

$$
K_{s}=\left[V_{M}^{\prime \prime \prime \prime}\right]^{2}\left[V_{\cdot} \cdot\right]^{3}
$$

The p-type nonstoichiometric reaction is given by

$$
\begin{gathered}
3 / 2 \mathrm{O}_{2}=V_{L a}^{\prime \prime \prime}+V_{\mathrm{Cr}, \mathrm{CO}}^{\prime \prime \prime}+6 h^{\circ}+30_{0} \\
K_{8}=\left[V_{M}^{\prime \prime \prime}\right]^{2} p^{6} P_{\mathrm{O} 2}{ }^{-3 / 2}
\end{gathered}
$$

When $\mathrm{Ca}^{2+}$ is substituted for $\mathrm{La}^{3+}$, the $\mathrm{Ca}^{2+}$ will possess one effective negative charge which can be compensated eithar by a $\mathrm{B}^{3+} \rightarrow \mathrm{B}^{4+}$ transition or by the formation of oxygen vacancies. This leads to the following overall electrical neutrality condition

$$
2\left[\mathrm{~V}_{0}^{\circ}\right]+p=6\left[\mathrm{~N}_{M}^{\prime \prime \prime}\right]+\left[C a_{M}^{\prime}\right]
$$

At high oxygen activity, electronic compensation is expected and assuming that both $\left[V_{0} \cdot\right]$ and $\left[V_{M}^{\prime \prime \prime}\right]$ are smaller than the impurity content, the neutrality condition becomes

$$
p=\left[C_{M}^{\prime}\right]
$$

and from Eqs. 7 and 9

$$
\begin{aligned}
& {\left[V_{M}^{\prime \prime \prime}\right]=K_{B}^{1 / 2} P_{O 2}{ }^{3 / 4} /\left[\mathrm{Ca}_{M}^{d}\right]} \\
& {\left[V_{\ddot{a}}\right]=K_{s}^{1 / 3}\left[C a_{M}^{\prime}\right] P_{O 2}{ }^{-1 / 2} / K_{8}^{1 / 3}}
\end{aligned}
$$

respectively:

At low oxygen activities, oxygen may be lost and ionic compensation takes place through the formation of oxygen vacancies. In this case the electrical neutrality condition becomes

$$
p=\left[C a_{M}^{\prime}\right]-2\left[V_{0}\right]
$$

This condition can be expressed by

$$
L a_{1-y} C a_{y}^{\prime} M^{x}{ }_{1-y} M_{y}^{\prime} O_{3}=L a_{1-y} C a_{y}^{\prime} M_{1-y+2 x}^{x} M_{y-2 x}^{\cdot} V_{\ddot{o x}} O_{3-x}+x / 2 O_{2}
$$

or simply by

$$
O_{0}+2 M_{M}^{\circ}=2 M_{M}^{x}+V_{0}+1 / 2 O_{2}
$$

where $y$ is the amount of dopant and $x$ is the concentration of oxygen vacancies. The equilibrium constant for reaction 14 can be expressed as

$$
K_{14}=\left[M_{M}^{x}\right]^{2}\left[\cdot \cdot P_{O 2}^{1 / 2} /\left[M_{M}^{\cdot}\right]^{2}\right.
$$


which in terms of mole fraction becomes

$$
K_{14}=(1-y+2 x)^{2} \times P_{O 2}^{1 / 2} /(y-2 x)^{2}
$$

Eq. 16 can be solved to yield

$$
\left.2 x=y-\left\{P_{O 2}{ }^{1 / 2}\left(8 \text { y } K_{14} P_{O 2}-1 / 2+1\right)^{1 / 2}-1\right) / 4 K_{14}\right\}
$$

Since the electrical conductivity for $p$-type materials is given by

$$
\sigma=\theta p \mu
$$

where $e$ is the electron charge, $\mu$ is the mobility, and $p$ is the concentration of carriers which, from the model, is equal to $y-2 x$. Thus, Eq. 18 can be rearranged to give

$$
\sigma=e \mathrm{P}_{\mathrm{O} 2}{ }^{1 / 2} \mu\left(\left(8 \text { y } \mathrm{K}_{14} \mathrm{P}_{\mathrm{O} 2}{ }^{-1 / 2}+1\right)^{1 / 2}-1\right) / 4 \mathrm{~K}_{14}
$$

At the high oxygen activity region, Eq. 17 reduces to $x=0$ and Eq. 19 reduces to $\sigma=e \mu y$, whereas in the low oxygen activity region the respective equations are reduced to

$$
p=(y-2 x) / y=P_{O 2}{ }^{1 / 4} /\left(2 y K_{14}\right)^{1 / 2}
$$

or

$$
\sigma=\left(\theta \mu y^{1 / 2} P_{O 2}{ }^{1 / 4}\right) / 2 K_{14}
$$

and

$$
\sigma / \sigma_{\mathrm{R}}=\mathrm{P}_{\mathrm{O} 2}{ }^{1 / 4} /\left(2 \mathrm{y} \mathrm{K}_{14}\right)^{1 / 2}
$$

where $\sigma_{R}$ is the electrical conductivity at 1 atm. oxygen.

The equilibrium constant $\mathrm{K}_{14}$ can thus be calculated by combining the electrical conductivity experimental data and Eq. 22. Theoretical curves can be generated by using Eq. 22 and the calculated values of $\mathrm{K}_{14}$. The individual symbols in figures 9-10 represent the experimental data while the lines are the calculated curves from the model. At high oxygen activity the electrical conductivity was independent of the oxygen activity due to the expected electronic compensation. At low oxygen activity the electrical conductivity exhibifed a $1 / 4$ power dependence on the oxygen activity. The switch from $\mathrm{P}_{\mathrm{O} 2}$ independent to $\mathrm{P}_{\mathrm{O} 2}$ dependent region occurred at $\sim 10^{-10}$ atmos at $1000^{\circ} \mathrm{C}$.

The stability of $\mathrm{La}_{1-x} \mathrm{Ca}_{x} \mathrm{Cr}_{1-y} \mathrm{Co}_{y} \mathrm{O}_{3}$ towards reduction is compared to that of $\mathrm{La}_{1-x} \mathrm{Sr}_{x} \mathrm{MnO}_{3}$ and $\mathrm{LaCr}_{1-x} \mathrm{Mg}_{\mathrm{x}} \mathrm{O}_{3}$ in Table IV and figure 11. Ca and Co doping significantl's increased the conductivity of $\mathrm{LaCrO}_{3}$ and extended its stability to lower oxygen activity. The compositions $\mathrm{La}_{1-x} \mathrm{Ca}_{x} \mathrm{Cr}_{1-y} \mathrm{Co}_{y} \mathrm{O}_{3}$ with $x=0.0-0.3$ and $y=0.1-0.2$ are found to be stable toward dissociation in forming gas at $1000^{\circ} \mathrm{C}$ even though the electrical conductivity does decrease because of the low oxygen activity ( $P_{\mathrm{O} 2} \simeq 10^{-16}$ atmos). 
Table IV. Electrical Conductivity of $\mathrm{La}_{8} \mathrm{Sr}_{.2} \mathrm{MnO}_{3}, \mathrm{LaCr}_{.95} \mathrm{Mg}_{.05} \mathrm{O}_{3}$ and $\mathrm{La}_{.8} \mathrm{Ca}_{.2} \mathrm{Cr}_{.8} \mathrm{Co}_{.1} \mathrm{O}_{3}$ as Function of Oxygen Activity at $1000^{\circ} \mathrm{C}$.

\begin{tabular}{|c|c|c|c|}
\hline $\mathrm{P}_{\mathrm{O} 2}$ (atm.) & $\begin{array}{c}\mathrm{La}_{.8} \mathrm{Sr}_{2} \mathrm{MnO}_{3} \\
\quad 0(\mathrm{~S} / \mathrm{cm}) \\
\end{array}$ & $\begin{array}{c}\mathrm{LeCr}_{.95} \mathrm{Mg}_{.05} \mathrm{O}_{3} \\
.9(\mathrm{~s} / \mathrm{cm}) \\
\end{array}$ & $\begin{array}{c}\mathrm{La}_{8} \mathrm{Ca}_{{ }_{2} \mathrm{Cr}_{9} \mathrm{Co}_{.1} \mathrm{O}_{3}} \\
{ }^{\prime}(\mathrm{s} / \mathrm{cm}) \\
\end{array}$ \\
\hline $\begin{array}{l}10^{0} \\
10^{-8} \\
10^{-10} \\
10^{-12} \\
10^{-14} \\
10^{-16}\end{array}$ & $\begin{array}{l}150 \\
150 \\
125 \\
65 \\
22 \text { (dissociated) } \\
10 \text { (dissociated) }\end{array}$ & $\begin{array}{l}3.2 \\
3.2 \\
3.2 \\
3.2 \\
2.5 \text { (stable) } \\
0.32 \text { (stable) }\end{array}$ & $\begin{array}{l}34 \\
34 \\
30 \\
25 \\
16 \text { (stable) } \\
9 \text { (stable) }\end{array}$ \\
\hline
\end{tabular}

The electrical conductivities were found to be inversely proportional to the Seebeck coefficients throughout the entire oxygen activity range. The Seebeck coefficient increased and the electrical conductivity decreased with decreasing oxygen activity. This is true for all the regions of oxygen excess, stoichiometry and oxygen deficiency. Since the investigated compounds were stable under reducing conditions as well as oxidizing conditions, no degradation was observed on the Seebeck measurements at $1000^{\circ} \mathrm{C}$, contrary to our observations on the $\mathrm{LaMnO}_{3}$ based perovskite oxides ${ }^{(14)}$. These findings are very encouraging and should be investigated further, inorder to identify the parameters that increase the conductivity while maintaining the stability of $\mathrm{LaCrO}_{3}$.

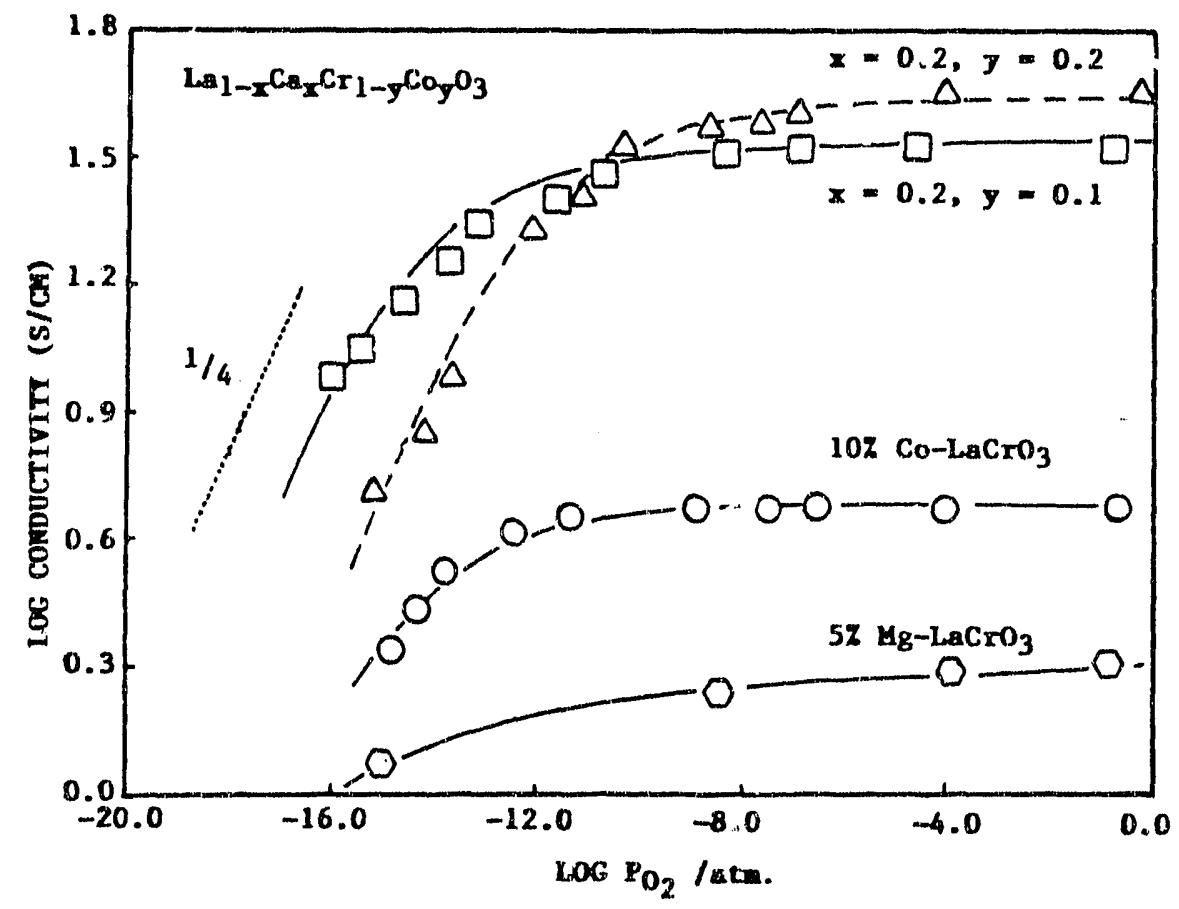

Figure 11: $\quad$ Log condictivity v8. $\log$ oxygen actlulty for doped $\mathrm{LaCrO}_{3}$ at $1000^{\circ} \mathrm{C}$ (Solid lines were derived from the model) 


\section{B. $\mathrm{YCrO}_{3}-\mathrm{YMnO}_{3}$ System}

The electrical conductivity of $\mathrm{Y}_{1-x} \mathrm{Ca}_{\mathrm{x}} \mathrm{CrO}_{3}$ was studied both as function of $\mathrm{Ca}$ content and oxygen activity. At $1000^{\circ} \mathrm{C}$, the maximum conductivity in air was $16 \mathrm{~S} / \mathrm{cm}$.

Examples of the electrical conductivity data are contained in figures 12,13 and 14.

The same model can be used to explain these data as that for $\mathrm{LaCrO}_{3}$ so will not be reproduced here.

A comparison between the reduction characteristics of $\mathrm{YCrO}_{3}, \mathrm{LaCrO}_{3}$ and $\mathrm{LaMnO}_{3}$ were made and we found that $\mathrm{Y}_{8} \mathrm{Ca}_{2} \mathrm{CrO}_{3}$ is more stable towards reduction than either $\mathrm{Sr}$ doped $\mathrm{LaMnO}_{3}$ or $\mathrm{LaCrO}_{3}$. (See figure 15)

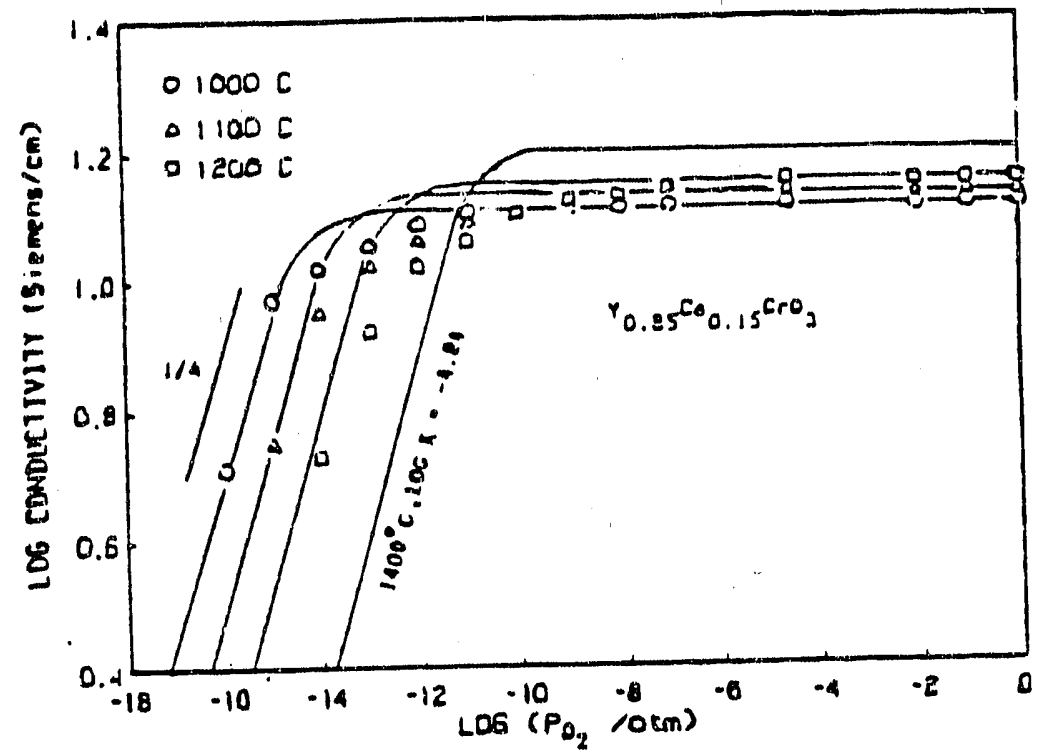

Figure 12a:

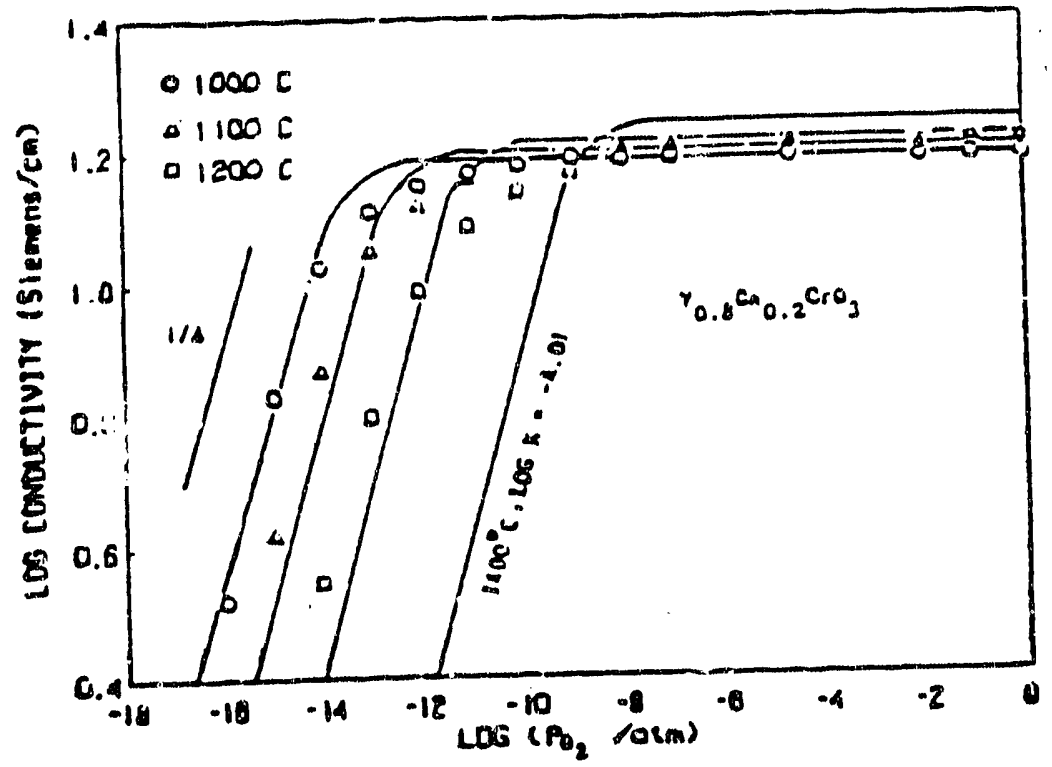

Figure 12b: Conductivity of $\mathrm{Y}_{.80} \mathrm{Ca}_{.20} \mathrm{CrO}_{3}(12 \mathrm{~b})$ and $\mathrm{Y}_{0.85} \mathrm{Ca}_{0.15} \mathrm{CrO}_{3}$ (12甘) as function of temperature and oxygen activity 


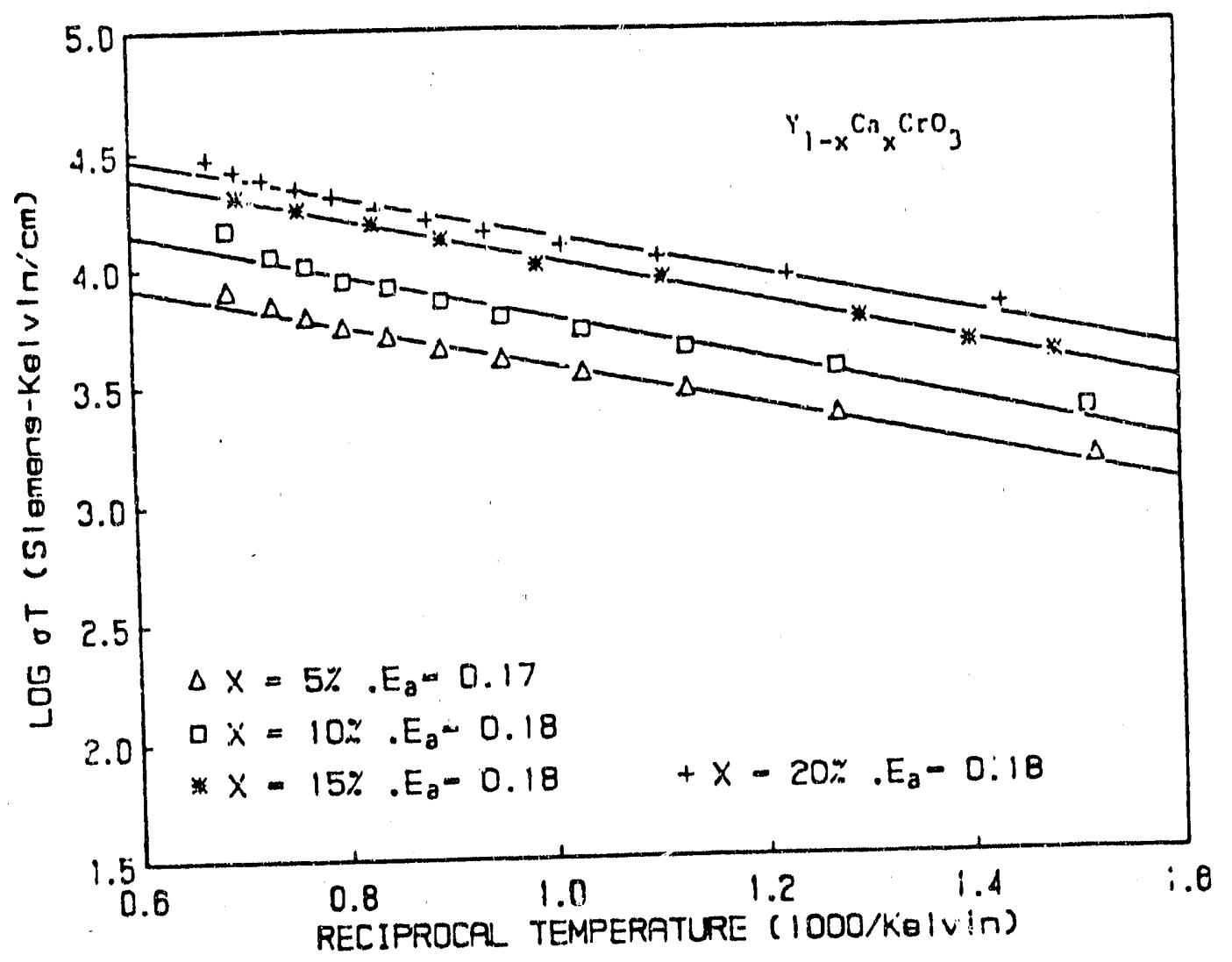

Figure 13: Log oT v8. reciprocal temperature for various Ca-dopant levels. The solid lines are calculated by the least squares method

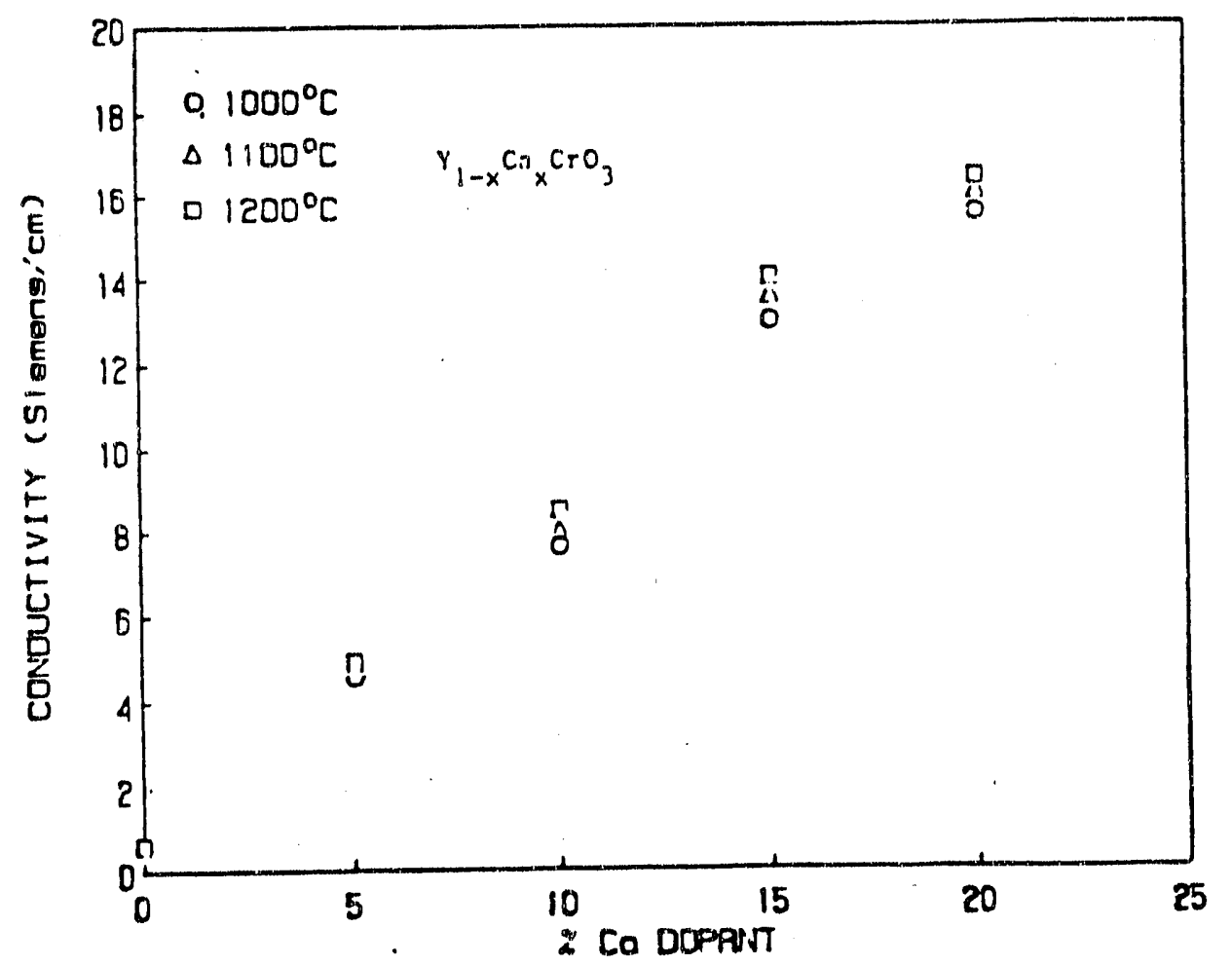

Figure 14: Conductivity v8. Ca-dopant concentration at varlous temperatures 


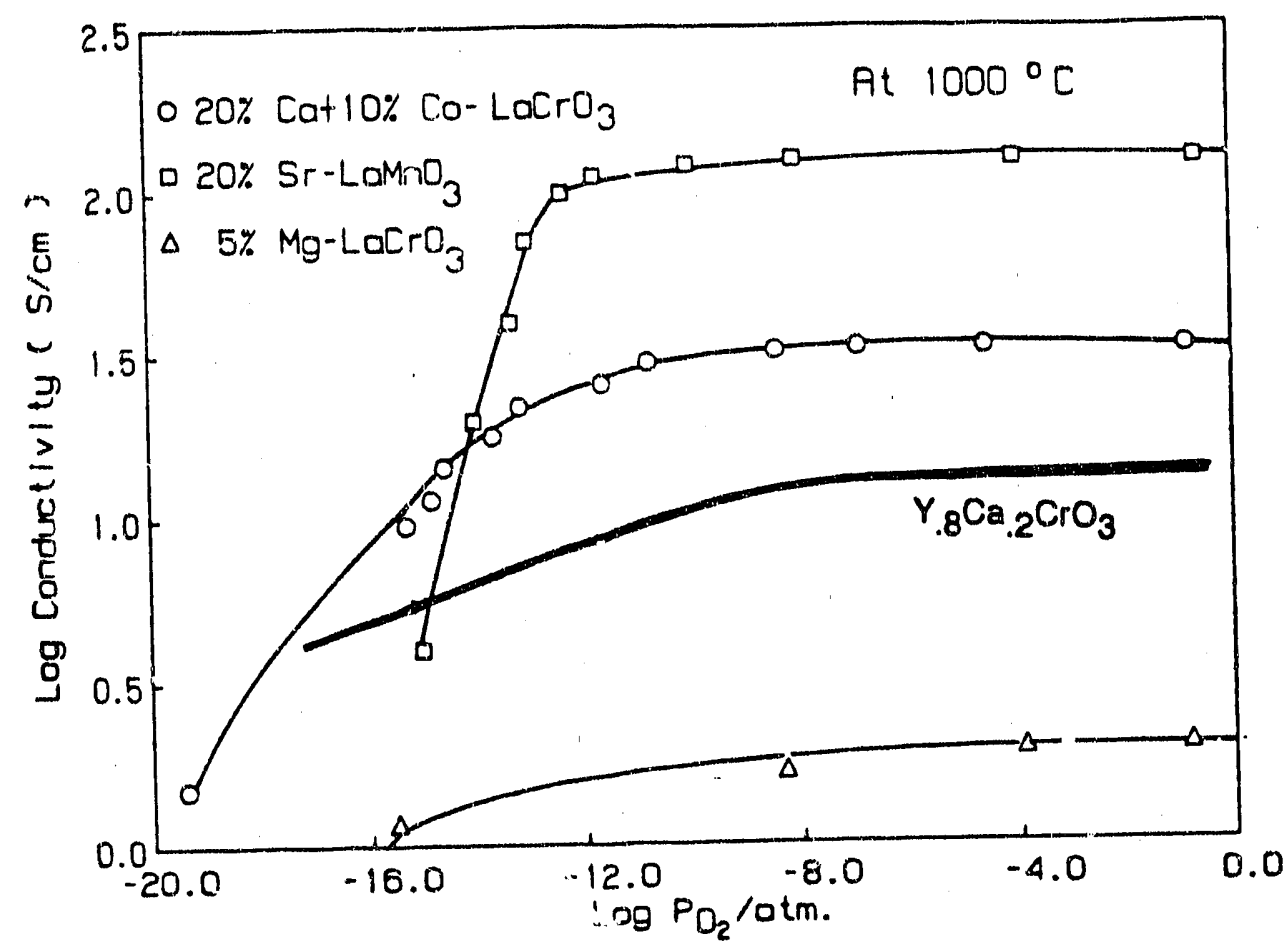

Figure 15: Comparison of electrical conductivity of $\mathrm{La}_{.8} \mathrm{Ca}_{.2} \mathrm{Cr}_{.8} \mathrm{Co}_{1 .} \mathrm{O}_{3}, \mathrm{La}_{.8} \mathrm{Sr}_{.2} \mathrm{MnO}_{3}$ and $\mathrm{LaCr}_{.95} \mathrm{M} \mathrm{Mr},{ }_{05} \mathrm{O}_{3}$ at $1000^{\circ} \mathrm{C}$ as function of axygen activity

Preliminary a.c. conductivity measurements indicate that some compositions in this series have high electrical conductivity, as shown below:

\begin{tabular}{ccc} 
Composition & C.onductivity (S/Cm) & Temp (C) \\
\cline { 2 - 2 } $\mathrm{Y}_{.9} \mathrm{Ca}{ }_{1} \mathrm{MnO}_{3}$ & 13.4 & $920^{\circ}$ \\
$\mathrm{Y}_{.8} \mathrm{Ca}_{.2} \mathrm{MnO}_{3}$ & 56.0 & $925^{\circ}$ \\
$\mathrm{Y}_{.7} \mathrm{Ca}_{.3} \mathrm{MnO}_{3}$ & 87.6 & $935^{\circ}$ \\
$\mathrm{Y}_{.6} \mathrm{Ca}_{.4} \mathrm{MnO}_{3}$ & 133.2 & $907^{\circ}$ \\
$\mathrm{Y}_{.5} \mathrm{Ca}_{.5} \mathrm{MnO}_{3}$ & 167.3 & $926^{\circ}$
\end{tabular}

The following activation energies were calculated:

Composition

$\mathrm{Y}_{.9} \mathrm{Ca}_{9} \mathrm{MnO}_{3}$

$\mathrm{Y}_{.8} \mathrm{Ca}_{2} \mathrm{MnO}_{3}$

$\mathrm{Y}_{.7} \mathrm{Ca}_{3} \mathrm{MnO}_{3}$

$\mathrm{Y}_{.6} \mathrm{Ca}_{4} \mathrm{MnO}_{3}$

$\mathrm{Y}_{.5} \mathrm{Ca}_{.5} \mathrm{MnO}_{3}$
Activation Energy $(\theta \mathrm{V})$

.26

.26

.19

.10

As can be seen the electrical conductivity of $\mathrm{Y}_{.6} \mathrm{Ca}_{.4} \mathrm{MnO}_{3}$ is as high as that of La ${ }_{.8} \mathrm{Sr}_{2} \mathrm{MnO}_{3}$. We know nothing regarding its stability towards reduction, but will be gathering that information soon. 


\section{C. $\mathrm{YCrO}_{3}-\mathrm{YMnO}_{3}-\mathrm{YCOO}_{3}$ System}

A survey of the electrical conductivity was made at $1000^{\circ} \mathrm{C}$ in air for the $\mathrm{YCrO}_{3}$ $\mathrm{YMnO}_{3}-\mathrm{YCOO}_{3}$ system (figure 16). Thuse data show that the maximum conductivities occur in the high $\mathrm{Co}$ and $\mathrm{Mn}$ concentration regions. However, since from other data we know that compositions containing more than $30 \mathrm{~m} \%$ of either Co or Mn will be unsta le towards reduction we focussed our attention to the $\mathrm{YCrO}_{3}$ corner of the diagram. As a result we have made some Ca doped formulations in the composition range 50 to $60 \mathrm{~m} \% \mathrm{Cr}, 10$ to $20 \mathrm{~m} \%$ $\mathrm{Ca}$ and 10 to $20 \mathrm{~m} \% \mathrm{Mn}$.

Figure 17 shows the electrical conductivity of compositions $\mathrm{Y}_{.7} \mathrm{Ca}_{.3} \mathrm{Cr}_{.5} \mathrm{Mn}_{3} \mathrm{Co}_{2} \mathrm{O}_{3}$ and $\mathrm{Y}_{.7} \mathrm{Ca}_{3} \mathrm{Cr}_{.6} \mathrm{Mn}_{.2} \mathrm{Co}_{.2} \mathrm{O}_{3}$ at $900^{\circ} \mathrm{C}$ as function of oxygen activity. The data show that these compositions are both electrically and structurally nearly as stable as $\mathrm{LaCrO}_{3}$ (See Figure 15). These results are very encouraging, but more work needs to be done to further define the best formutations (with electrical conductivity in air $>60 \mathrm{~S} / \mathrm{cm}$ ).

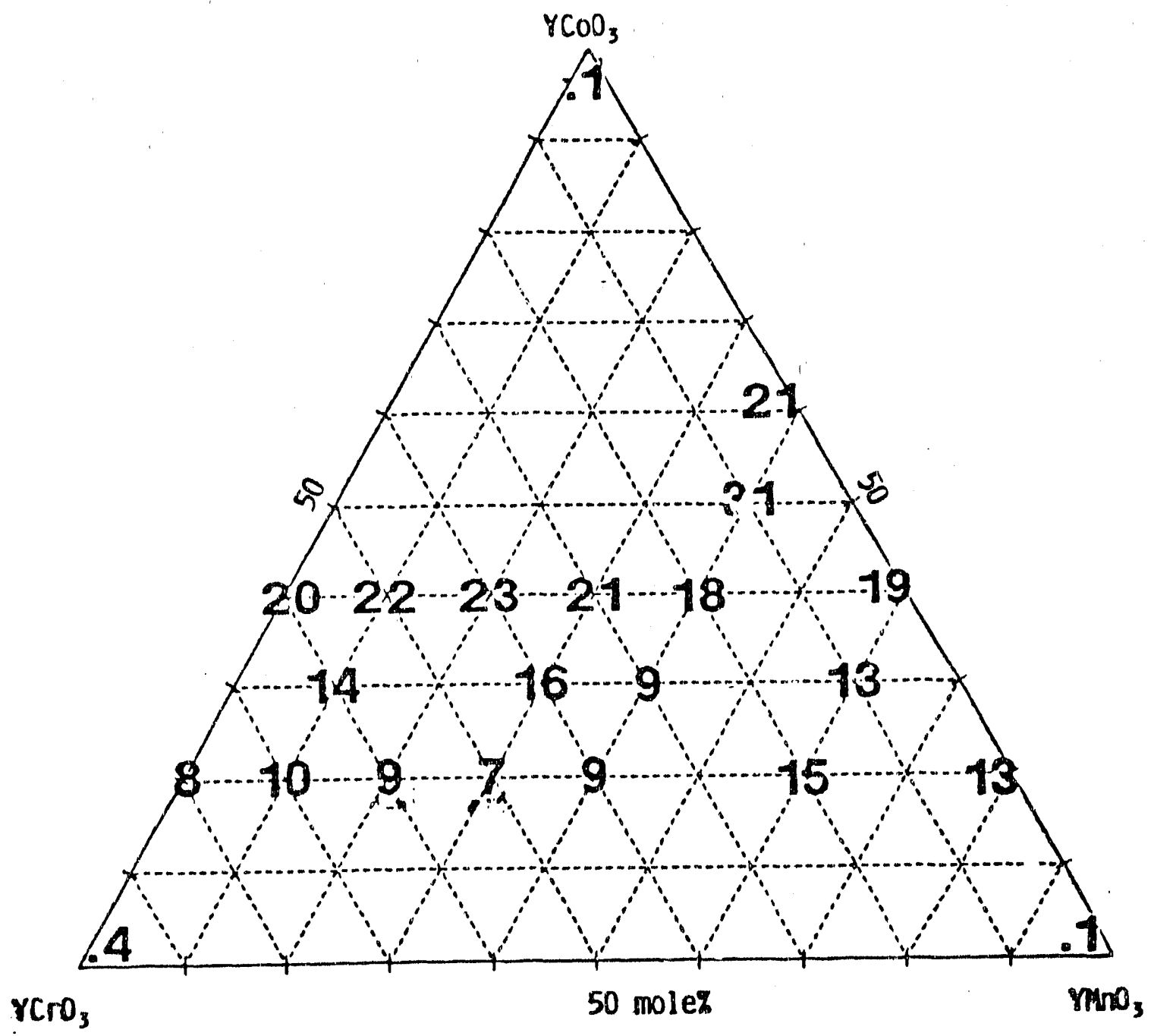

Figure 16: de conductivity $1000^{\circ}(\mathrm{S} / \mathrm{cm})$ 


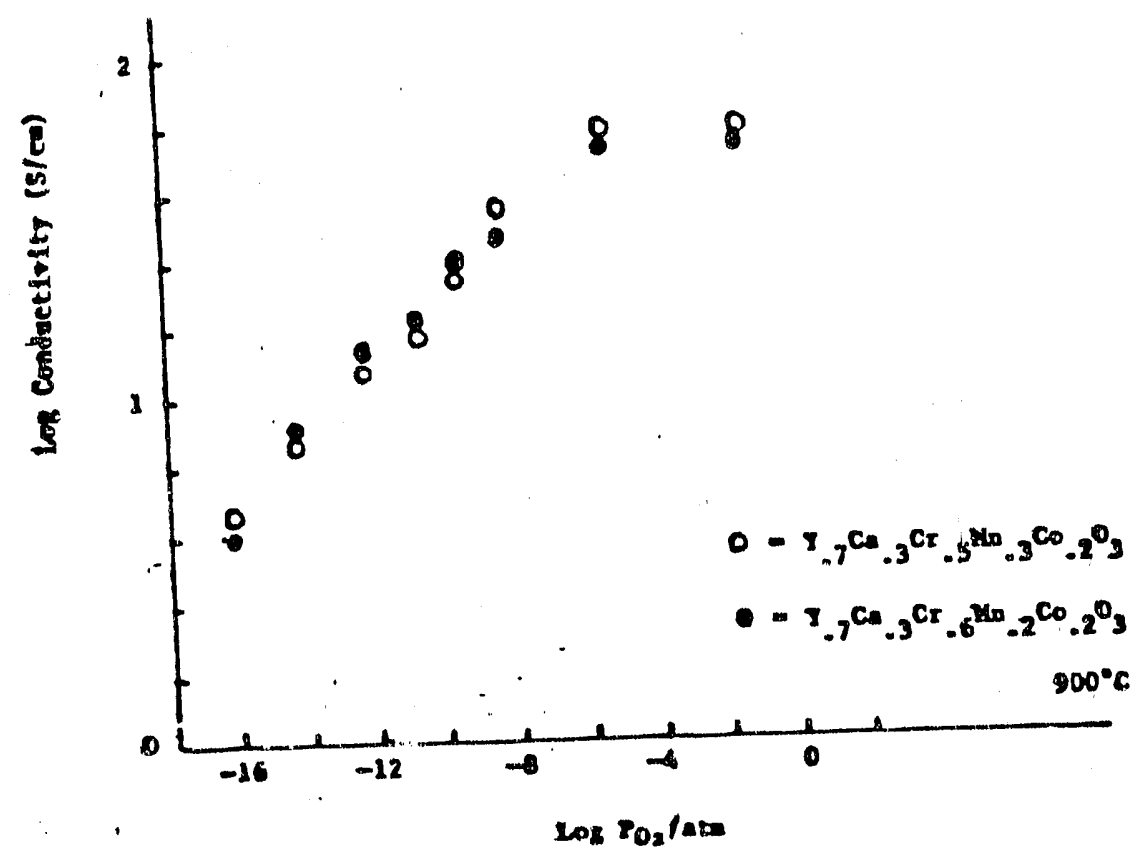

Figure 17: Electrical conductivity of $\mathrm{Y}_{7} \mathrm{Ca}_{.3} \mathrm{Cr}_{.5} \mathrm{Mn}_{.3} \mathrm{Co}_{.2} \mathrm{O}_{3}$ and $\mathrm{Y}_{.7} \mathrm{Ca}_{.3} \mathrm{Cr}_{.6} \mathrm{Mn}_{.2} \mathrm{Co}_{.2} \mathrm{O}_{3}$ as function of oxygen activity at $90^{\circ} 0^{\circ} \mathrm{C}$

\section{Thermal Expansion Coefficient}

All of the thermal expansion coefficient (TEC) data taken during the course of this program will be tabulated in this section. Although, we observe specific parameters that affect the TEC of various compounds upon doping, however, at the moment we offer no explanation for the trends.

\section{A. $\quad \mathrm{LaCrO}_{3}-\mathrm{LaCOO}_{3}$ System}

The thermal expansion coefficients were determined and given in Tables $\mathrm{V}$ and $\mathrm{VI}$ as a function of $\mathrm{Co}$ and $\mathrm{Ca}$ substitution. The TEC increased with increasing Co content. This must be due to the high thermal expansion coefficient of $\mathrm{LaCoO}_{3}$ which was reported to be approximately $22 \times 10^{-6} \% \mathrm{C}$. The TEC of compositions with $y>0.5$ changed little with further increase in Co content and remained in the region of $20-23 \times 10^{-6} \% \mathrm{C}$. However, when co conient was further decreased the TEC values decreased to $13.1 \times 10^{-6} \% \mathrm{C}$ at $\mathrm{y}=0.1$.

Additional Ca substitution for La decreased the TEC. The TEC of $\mathrm{La}_{.7} \mathrm{Ca}_{3} \mathrm{Cr}_{.9} \mathrm{Co}_{.1} \mathrm{O}_{3}$ had a value of $10.4 \times 10^{-6} \% \mathrm{C}$. This value matches that of Y-PSZ. Therefore, the thermal expansion coefficient of the $\mathrm{LaCrO}_{3}$ can be increased to match those of the other SOFC components by $\mathrm{Co}$ and $\mathrm{Ca}$ substitutions. The substitution of $\mathrm{Ca}$ for $\mathrm{La}$ in the $\mathrm{LaCr}_{1-\mathrm{y}} \mathrm{Co}_{y} \mathrm{O}_{3}$ resulted in formation of $\mathrm{Cr}^{4+}$ and $\mathrm{Co}^{4+}$ in order to maintain the electrical neutrality.

Formation of both $\mathrm{Cr}^{4+}$ and $\mathrm{Co}^{4+}$ decrease the unit cell volume, since in these valence states 
the radius of $\mathrm{Cr}^{4+}$ and $\mathrm{Co}^{4+}$ ions is markedly lower than that of $\mathrm{Cr}^{3+}$ and $\mathrm{Co}^{3+}$. The decrease in TEC with increasing Ca cortent is probably associated with the formation of $\mathrm{Cr}^{4+}$ and $\mathrm{Co}^{4+}$ ions.

Table V. Thermal Expanaion Coefficients as a Function of Co

\begin{tabular}{cc}
\multicolumn{2}{c}{$\mathrm{LaCr}_{1, y} \mathrm{Cl}_{y} \mathrm{O}_{3}\left(100-1100^{\circ} \mathrm{C}\right)$} \\
Composition $(v)$. & TEC $\left(10^{-6} \mu^{\circ} \mathrm{C}\right)$ \\
\hline 0.0 & 9.50 \\
0.1 & 13.10 \\
0.2 & 13.60 \\
0.3 & 15.90 \\
0.5 & 21.80 \\
0.7 & 22.30 \\
0.9 & 22.80 \\
1.0 & 23.20
\end{tabular}

Table VI. Thermal Expansion Coefficients as a Function of $\mathbf{C a}$

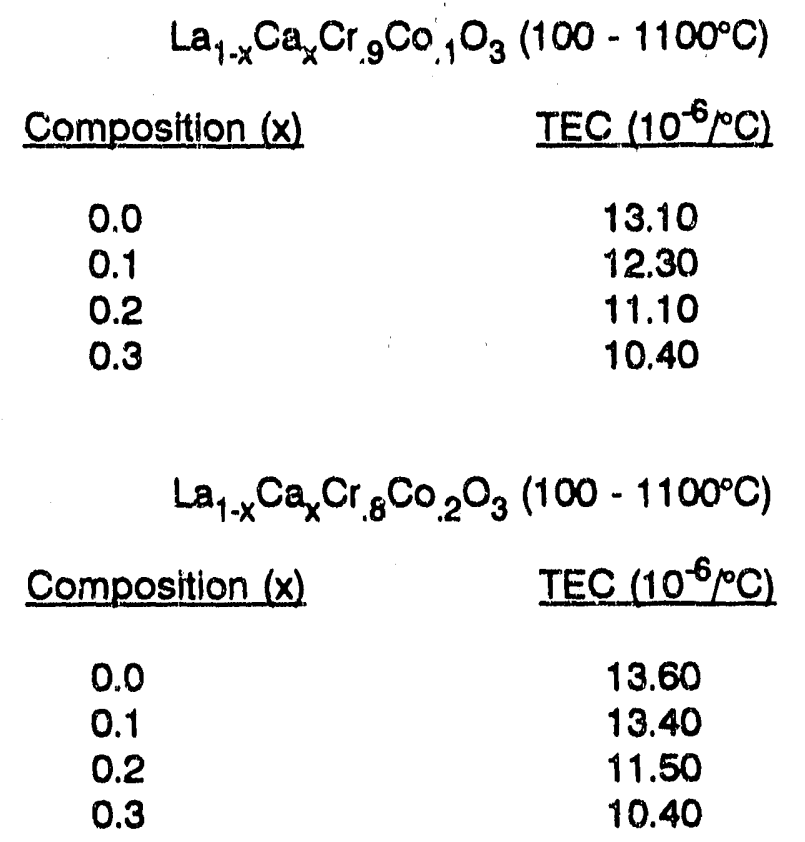

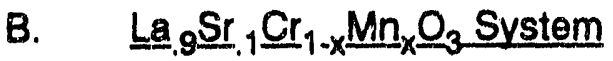

Table VII shows the dependence of the thermal expansion coefficient on Mn content. As can be seen the TEC increases as the Mn content increases. 
Table VII. Thermal Expansion La.9 $\mathrm{Sr}_{.1} \mathrm{Cr}_{1-x} \mathrm{Mn}_{\mathrm{x}} \mathrm{O}_{3}$

\begin{tabular}{cc} 
Mn Content & TEC $\times 10^{6} \mathrm{C}^{-1}$ \\
\cline { 2 - 2 } $0 \mathrm{m \%}$ & 10.7 \\
10 & 9.6 \\
20 & 10.0 \\
30 & 9.5 \\
40 & 10.0 \\
50 & 10.5 \\
60 & 10.1 \\
70 & 10.4 \\
80 & 11.8 \\
90 & 11.5 \\
100 & $11.6-12.0$ \\
\hline
\end{tabular}

c. $\mathrm{YCrO}_{3}-\mathrm{YCOO}_{3}-\mathrm{YMnO}_{3}$

Higure 18 shows the room temperature $X$-ray diffraction analysis results. As can be seen most of the compositions are orthorhombic. We found it difficult to sinter compositions along the binary tie lines. The compositions in the ternary regions all terided to sinter well. We are now starting to add $\mathrm{Ca}$, so we may find changes in the densification characteristics. Figure 19 shows the thermal expansion coefficient in this system.

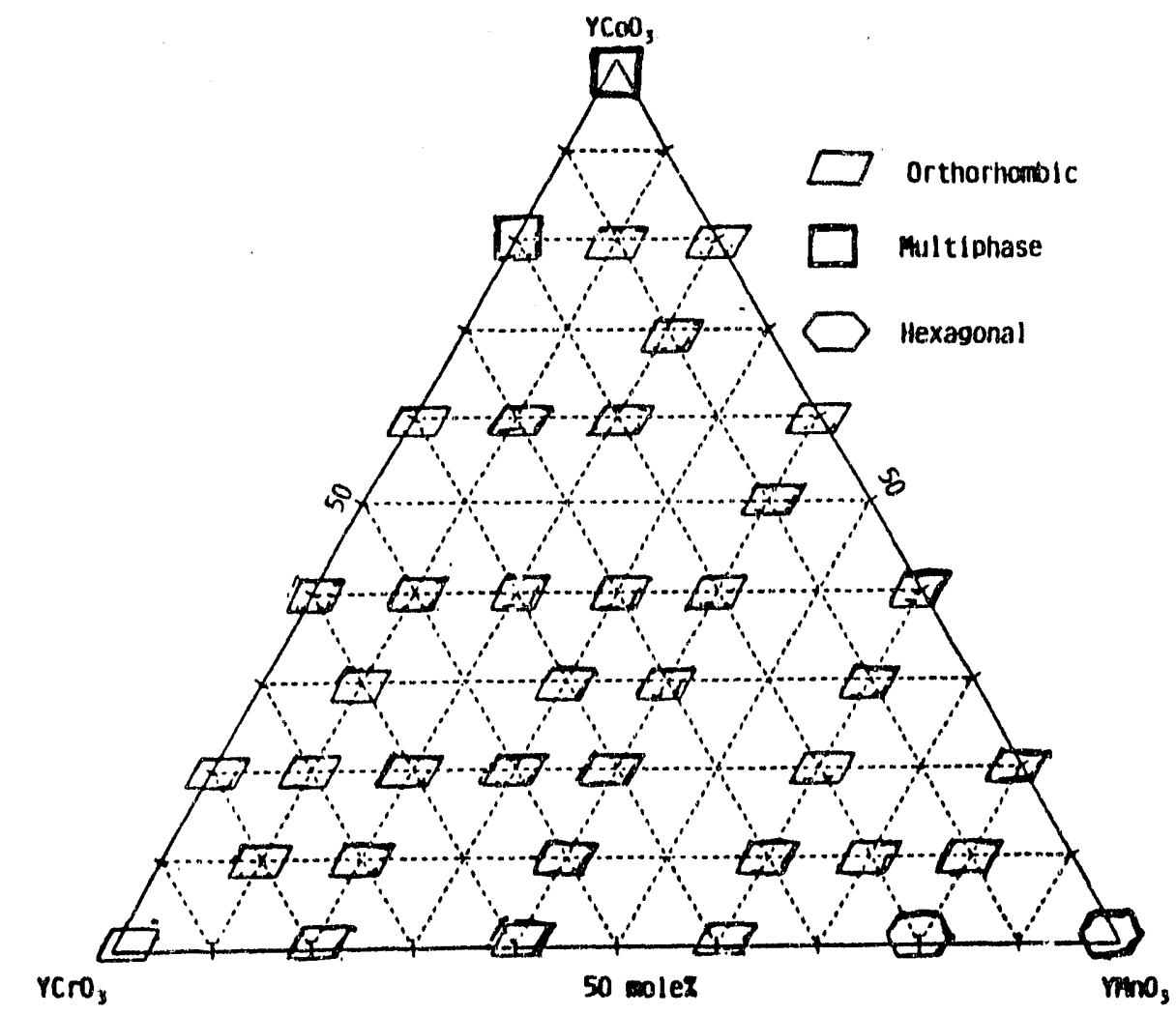

Figure 18: Crystal structure $1100^{\circ} \mathrm{C}$ 


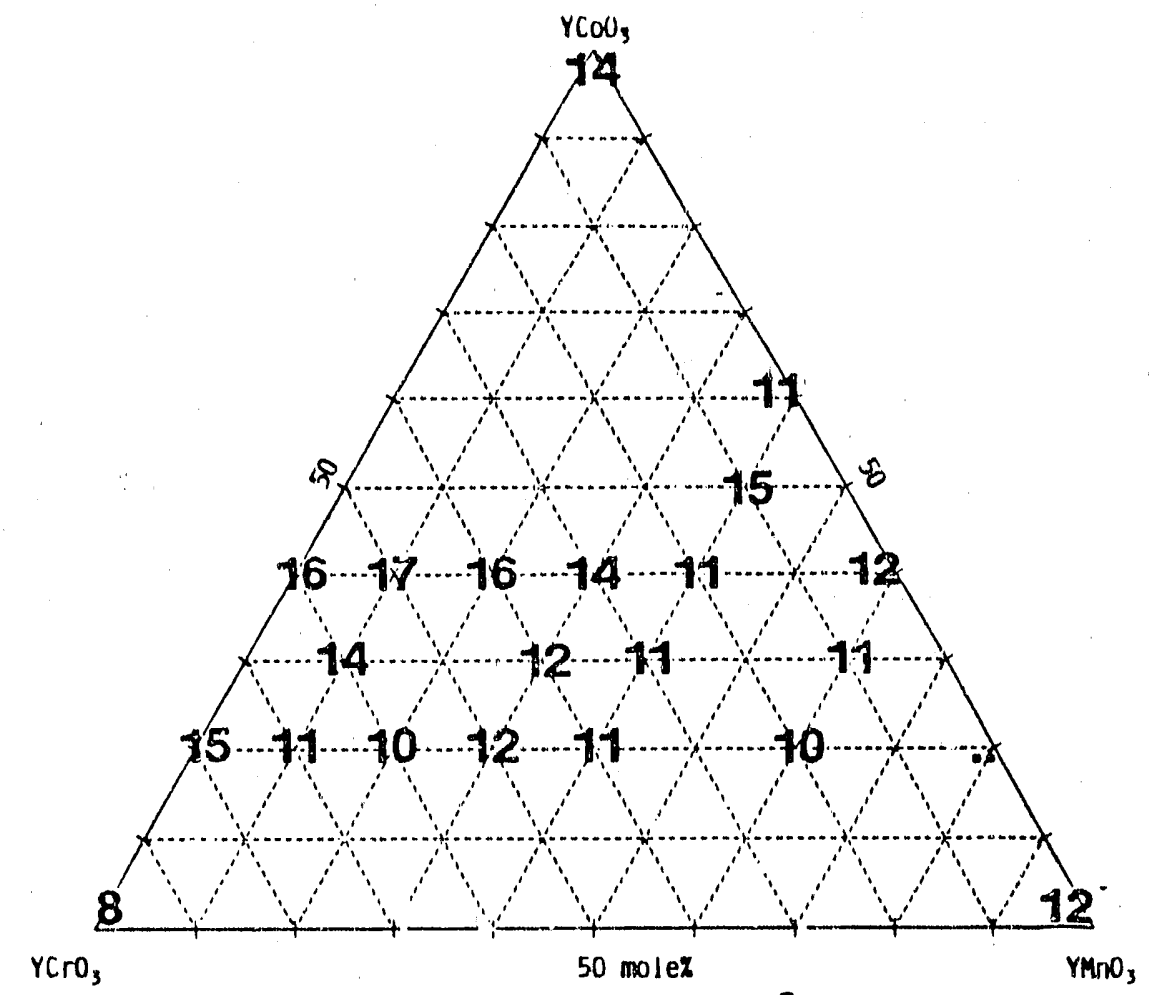

Figure 19: Thermal expansion $500-1000^{\circ} \mathrm{C}\left(\propto * 10^{+6}\right)$

D. $\mathrm{LaCrO}_{3}$

The thermal expansion of $\mathrm{LaCrO}_{3}$ was measured as function of $\mathrm{Sr}$ and $\mathrm{Mg}$ content.

These data are listed in Table VIII. The data show that $\mathrm{Sr}$ doping can yield a TEC match with Zirconia.

Table VIII. Thermal Expansion Coefficients of $\mathrm{Ca}, \mathrm{Mg}$ and Sr-Doped $\mathrm{La} .99 \mathrm{CrO}_{3}$

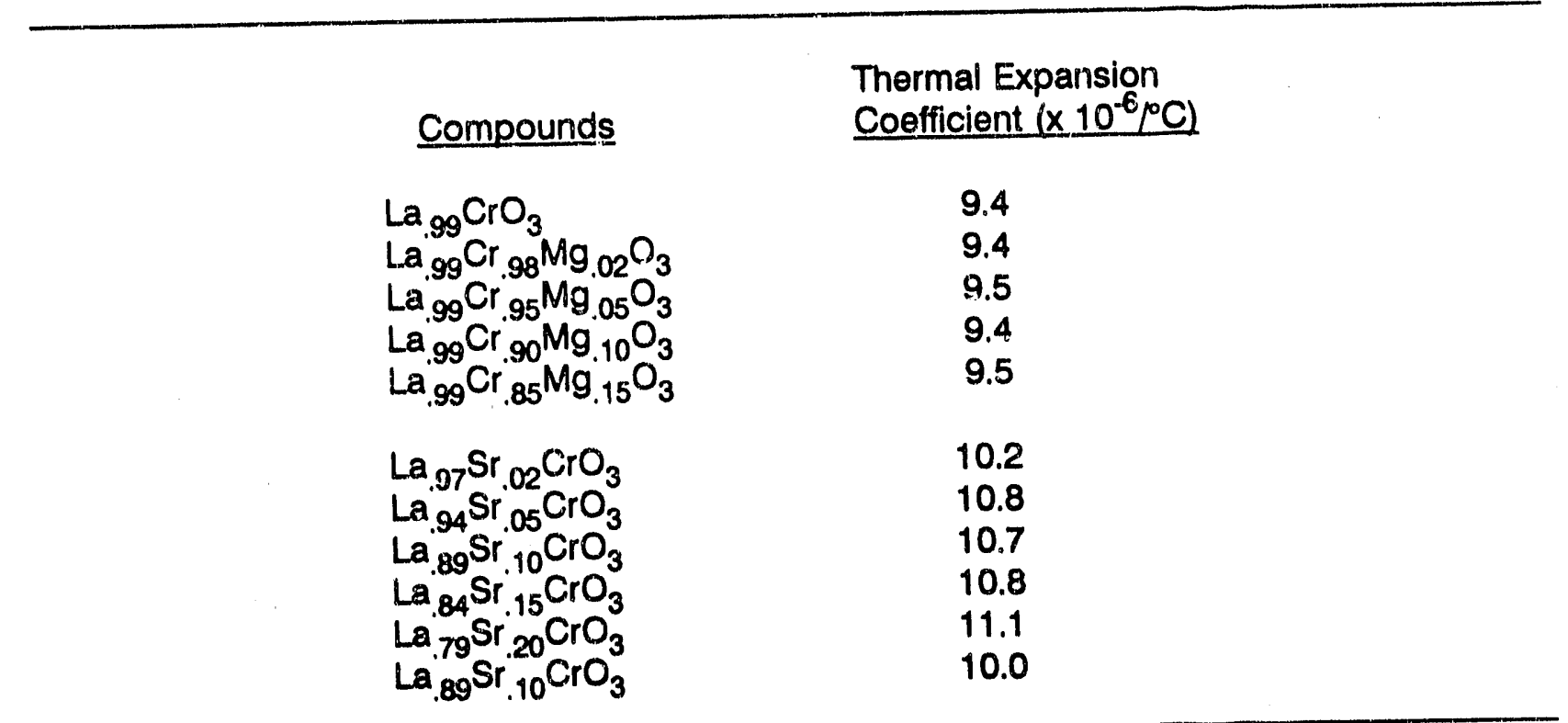

* Temperature range from 350 to $1000^{\circ} \mathrm{C}$. 


\section{E. $\quad \mathrm{LaMnO}_{3}$}

The thermal expansion of $\mathrm{LaMnO}_{3}$ was measured as function of $\mathrm{Sr}$ content (Table IX). As can be seen, the TEC is graster than that of zirconia for all compositions.

\section{Table IX.}

Composition

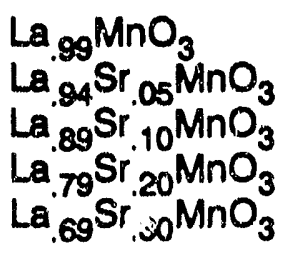

$\underline{a \times 10^{6} p \mathrm{C}}$

$11.2 \pm 0.3$

11.7

12.0

12.4

12.8

\section{F. $\quad \mathrm{YCrO}_{3}$}

The thermal expansion of $\mathrm{YCrO}_{3}$ was measured as function of $\mathrm{Ca}$ content (fig. 20). Although $\mathrm{Ca}$ doping increased the $\mathrm{TEC}$ of $\mathrm{YCrO}_{3}$, however, at the solubility limit of $\mathrm{Ca}$ in $\mathrm{YCrO}_{3}$ the TEC is less than that of zirconia.

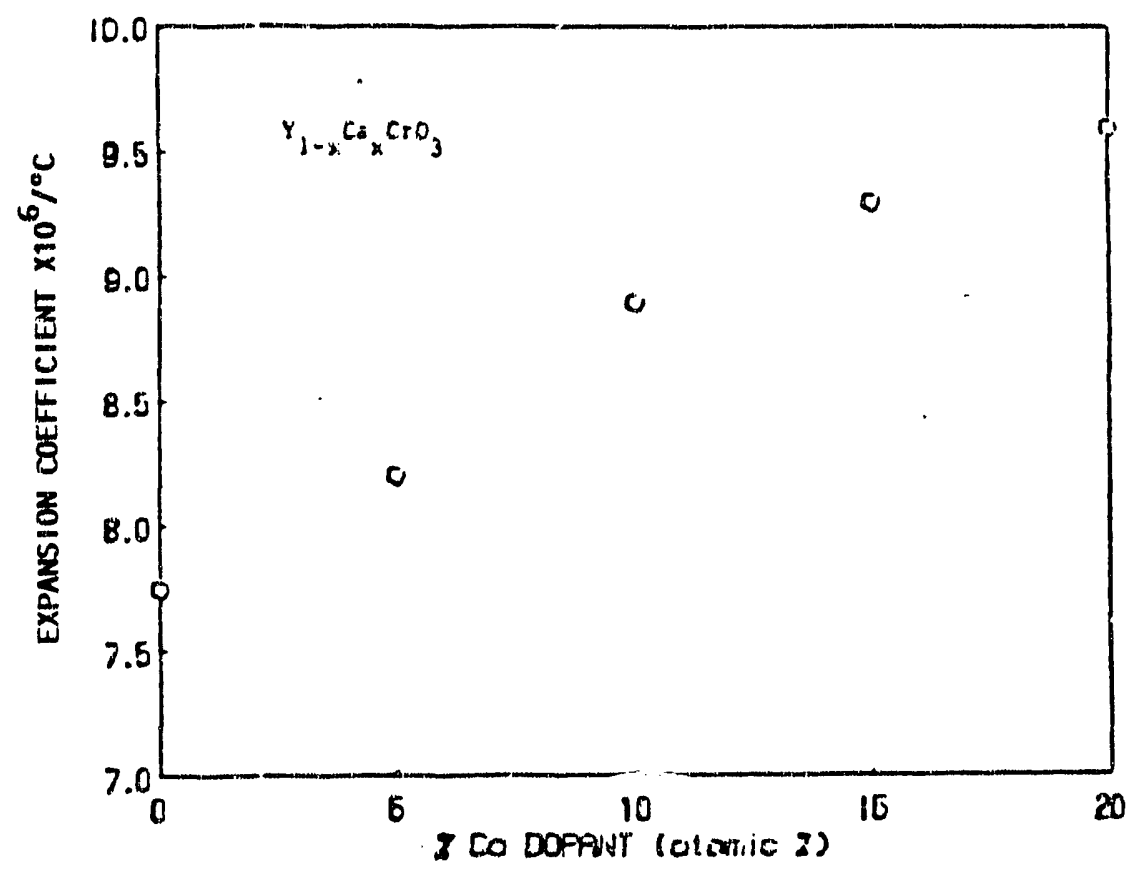

Figure 20.

N. Films of La $7 \mathrm{Ca}_{3} \mathrm{Cr}_{1 \times x} \mathrm{CO}_{x} \mathrm{O}_{3}$ on Stabilized $\mathrm{ZrO}_{2}$ Substrates

Inks were prepared of powders of composition $\mathrm{La}_{.7} \mathrm{Ca}_{3} \mathrm{Cr}_{.8-95} \mathrm{Co}_{.05-.2} \mathrm{O}_{3}$ and either

printed or painted onto dense $\mathrm{ZrO}_{2}$ plates. Good adhesion and sintering was observed after 
heat treatment in the 1300 to $1400^{\circ} \mathrm{C}$ range. Porosity appears to be controllaisle so that such coatings can be used as a cathode.

The sintering study showed that the optimum temperature range is 1300 to $1350^{\circ}$. Figure 21 is a SEM of La ${ }_{7} \mathrm{Ca}_{3} \mathrm{Cr}_{.9} \mathrm{Co}_{.1} \mathrm{O}_{3}$ sintered on a YSZ substrate at $1350^{\circ} \mathrm{C}$ for 2 hours. This film is well sintered and as shown in Figure 22 is well bonded to the YSZ substrate. Figure 23 shows the same ink sintered at $1400^{\circ} \mathrm{C}$ for 2 hours. This film is quite dense and well sintered but the porosity is too low for use as a cathode for SOFC. At $1350^{\circ} \mathrm{C}$, it appears that with a few adjustments in the ink, a porosity can be obtained that will allow the film to serve as a cathode for SOFC's.

In the future we will be attempting to optimize our inks and make some electrical conductivity measurements of the films.

We have also demonstrated our ability ${ }^{(16,17)}$ to make films of $\mathrm{La}_{1-x} \mathrm{Sr}_{x} \mathrm{MnO}_{3}$ on $\mathrm{YSZ}$. substrates. Dense $(0.3 \mu \mathrm{m})$ as well as porous $(5-25 \mu \mathrm{m})$ films were developed.

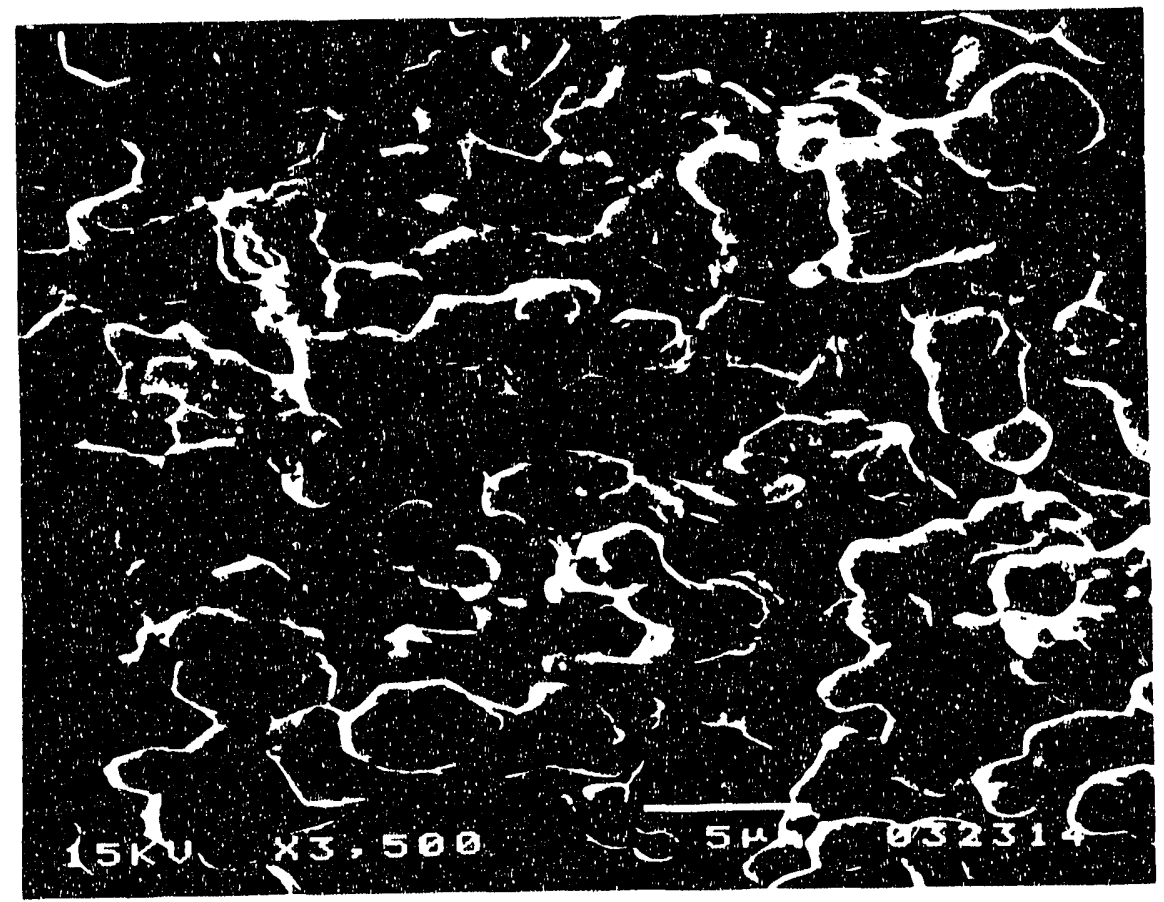

Figure 21: SEM Photomicrograph of Surface of $\mathrm{La}_{.7} \mathrm{Ca}_{3} \mathrm{Cr}_{.8} \mathrm{Co}_{.1} \mathrm{O}_{3} \mathrm{Film}$ on YSZ $T=1350^{\circ} \mathrm{C} / 2 \mathrm{hr}$. 


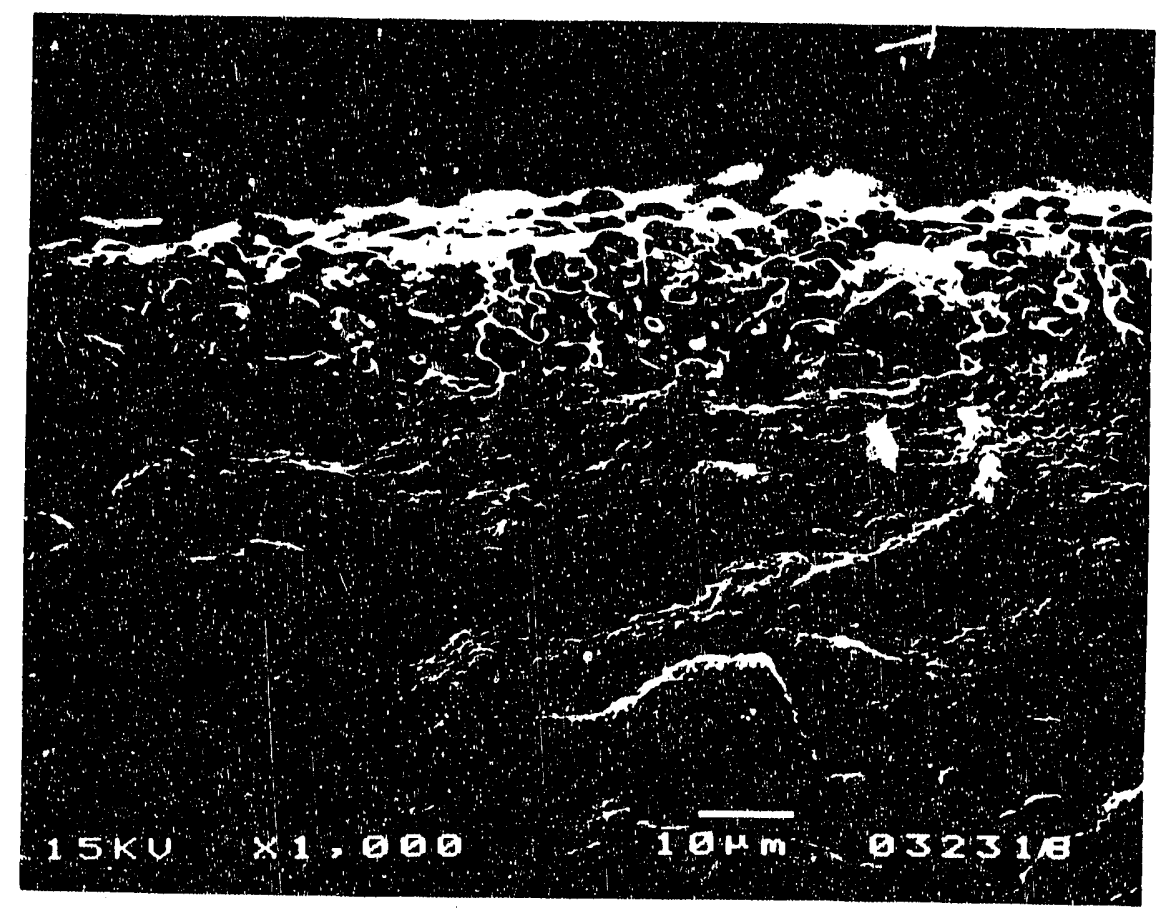

Figure 22: Scanning Elcctron Microscope Photomicrograph of Fracture Surface of a La. ${ }_{.7} \mathrm{Ca}_{.3} \mathrm{Cr}_{.9} \mathrm{Co}_{.1} \mathrm{O}_{3}$ Film on YSZ, $\mathrm{T}=1350^{\circ} \mathrm{C} / 2 \mathrm{hr}$, Thickness $\simeq 20-25 \mu \mathrm{m}$.

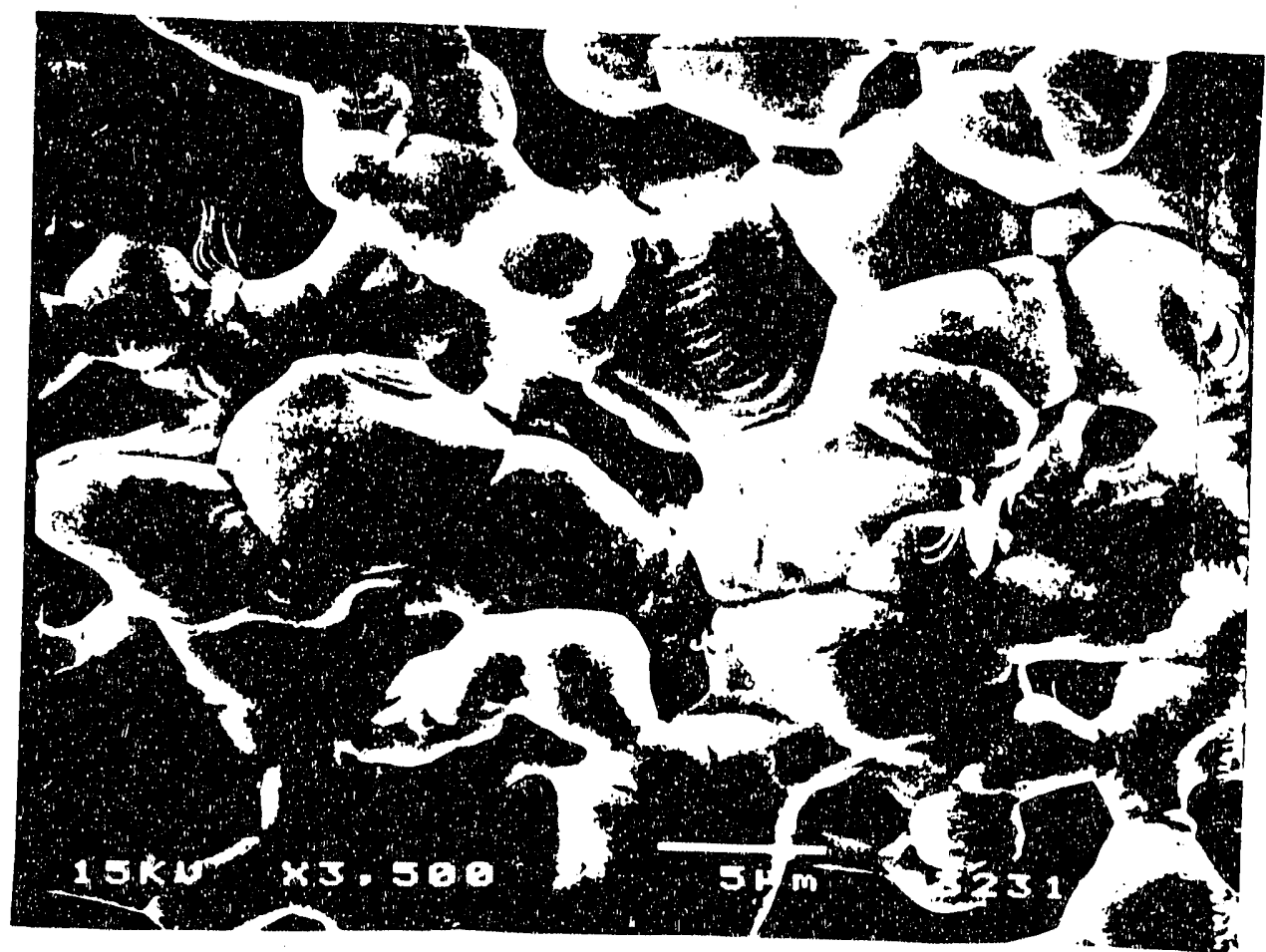

Figure 23a: SEM Photomicrograph of Surface of $\mathrm{La}_{.7} \mathrm{Ca}_{.3} \mathrm{Cr}_{.8} \mathrm{Co}_{.1} \mathrm{O}_{3}$ Film on YSZ, $T=i 400^{\circ} \mathrm{C} / 2 \mathrm{hr}$. 


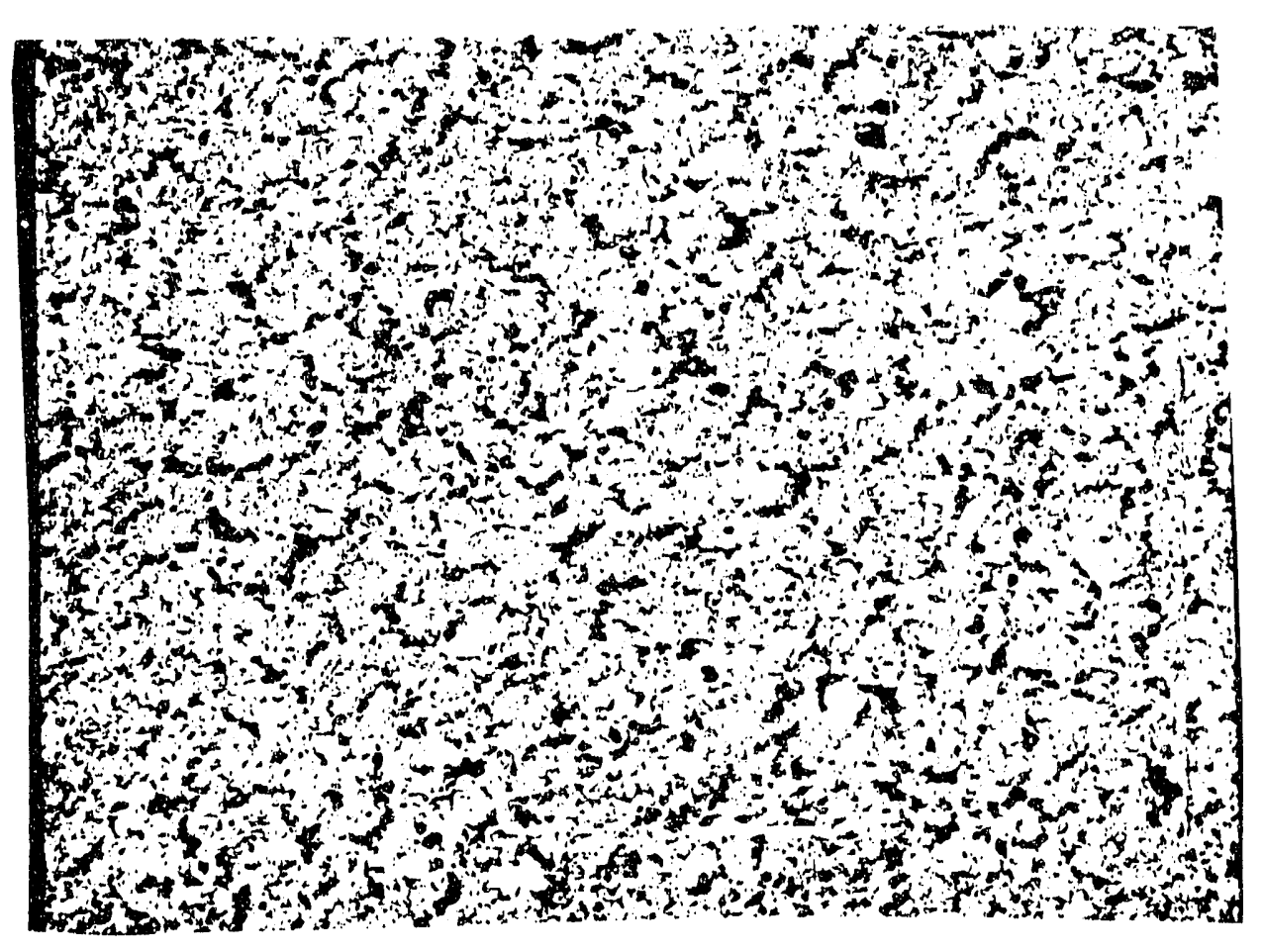

Figure 23b: SEM Photomicrograph of Surface of a $\mathrm{La}_{.7} \mathrm{Ca}_{.3} \mathrm{Cr}_{.9} \mathrm{Co}_{.1} \mathrm{O}_{3}$ Film on $\mathrm{YSZ}$, $T=1400^{\circ} \mathrm{C} / 2 \mathrm{hr}$.

\section{Accomplishments and Conclusions}

Although the entire time frame of this program was only 16 months, yet significant progress has been made towards the development of improved cathode materials. The highlights of our accomplishments include:

1. The results are very encouraging since the stability towards reduction in fuel gas is improved, and electrical conductivity of $60 \mathrm{~S} / \mathrm{cm}$ at $1000^{\circ} \mathrm{C}$ is achieved. Thus, we have developed a system which does not raduce in fuel gas, and has a conductivity within $50 \%$ of that of $\mathrm{La}_{.8} \mathrm{Sr}_{.2} \mathrm{MnO}_{3}$.

2. We have prepared $1 \mathrm{Kg}$ quantities of a potential composition for cathode applications $\left(\mathrm{La} .79 \mathrm{Ca}_{.2} \mathrm{Cr}_{.9} \mathrm{Co}_{.1} \mathrm{O}_{3}\right)$ and delivered them to AirResearch and Westinghouse for evaluations as per our program commitment.

3. We have shown that the $\mathrm{La}_{1-x} \mathrm{Ca}_{x} \mathrm{Cr}_{1-y} \mathrm{Co}_{y} \mathrm{O}_{3}$ system has thermal expansion coefficients ranging from $10.5 \times 10^{-6} \% \mathrm{C}$ to $11.5 \times 10^{-6} \% \mathrm{C}$.

4. $\quad \mathrm{La}_{.7} \mathrm{Ca}_{.3} \mathrm{Cr}_{1-x} \mathrm{Co}_{x} \mathrm{O}_{3}$ powders were sintered onto $\mathrm{YSZ}$ plates. Good adhesion and sintering were observed upon heat treatment in the $1300^{\circ}$ to $1400^{\circ} \mathrm{C}$ range with $X=$ $0.05 \%$. The porosity appears to be controllable so that such cuatings can be used as cathodes. 
5. The stability of $\mathrm{Y}_{.7} \mathrm{Ca}_{.3} \mathrm{Cr}_{.5} \mathrm{Mn}_{.3} \mathrm{Co}_{.2} \mathrm{O}_{3}$ and $\mathrm{Y}_{.7} \mathrm{Ca}_{.3} \mathrm{Cr}_{.6} \mathrm{Mn}_{.2} \mathrm{Co}_{.2} \mathrm{O}_{3 .}$ towards reduction was evaluated at $900^{\circ} \mathrm{C}$. The results show that these compositions are quite statle and are potential candidates for cathode applications. Work should continue in this area.

6. We have started our reduction stability studies of the $\mathrm{YCrO}_{3}-\mathrm{YMnO}_{3}-\mathrm{YCoO}_{3}$ system. Our results to date suggest that this system may yield a good cathode material. Work should be continued here. It is encouraging to realize that $\mathrm{Y}_{.6} \mathrm{Ca}_{.4} \mathrm{MnO}_{3}$ has conductivities comparable to those of $\mathrm{La}_{.8} \mathrm{Sr}_{.2} \mathrm{MinO}_{3}$. We plan to complete these studies but not during our contract period. Our focus will be on compositions with high $\mathrm{Cr}$ content in this system.

7. Our results suggest that we need to continue our investigation on the effect cf multiple substitution on both the $\mathrm{A}$ and $\mathrm{B}$ lattice site of $\mathrm{LaCrO}_{3}$ with cations which have variable valences as we suggested in our proposal. We have done some of this, however, we did not complete this task within the contract period. This is probably the only method by which we can increase the hole mobility in $\mathrm{LaCrO}_{3}$ sufficiently for cathode applications. This is a gocd area for future studies.

8. Our efforts within the frame work and duration of this project resulted in several publications and presentations in international meetings. These were supported either fully or in part by this program. A list is shown in section 7.

\section{References}

1. G. Carini II, "An Apparatus for the Measurement of dc Electrica Conductivity and Seebeck Coefficient of Semiconductors as a Function of High Temperature and Oxygt 7 Partial Pressure", M.S. Thesis, University of Missouri-Rolla, 1987.

2. M.P. Pechini, "Method of Preparing Lead and Alkaline Eartr. Titanates and Niobates and Coating Method Using the Same to From a Capacitor", U.S. Patent No. 3,330,697, July 1967.

3. L. Groupp and H.U. Anderson, The Influerice of Oxygen Activity on Sintering of SrDoped Lanthanum Chromite", J. of Amer. Cer. Soc., 59, 449-53, 1976.

4. D.B. Meadowcroft, "Some Properties and Application of Strontium-Doped Rare- Earth Perovskites", Proceeding of the Conference on Sr Containing Cumpounds, 118-35, 1973.

5. B.K. Flandermeyer, R.B. Poeppel, J.T. Dusek and H.U. Anderson, "Sintering Aid For Lanthanum Chromite Refractories", U.S. Patent \#4,749,632, 1988. 
6. D.P. Karim and A.T. Aldred, "Locallzed Level Hopping Transport in La(Sr) $\mathrm{CrO}_{3}$ ", Phys. Rev. B, 20, 6, 2255-63, 1979.

7. S. Song, M. Yoshimura and S. Somiya, "i-tydrothermal Synthesis of $\left(L a_{1 \cdot x} C a_{x}\right) C r O_{3}$ ", J. Mater. Sci. Soc. Jpn., 19, No. 1, 49, 1982.

8. P.M. Raccah and J.B. Goodenough. "First-Order Localized-Electron Versus Collective Electron Transition in $\mathrm{LaCoO}_{3}{ }^{\prime}$, Phys. Rev. 155, 932, 1967.

9. H. Taguchi, M. Shimada and M. Koizumi, "Electrical Properties in the System (La, $\left.{ }_{x} \mathrm{Ca}_{\mu}\right) \mathrm{CoO}_{3}(0.1<x<0.5)^{n}$, J. of Solid State Chemistry, 44, 254-56, 1982.

10. P.M. Raccah and J.B. Goodenough, " $\mathrm{A}$. Localized-Electron to Collective-Electron Transition in the System (La,Sr)CoO ${ }_{3}{ }^{\prime \prime}$, J. of Appl. Phys., 39, 2, 1209-12, 1968.

11. H. Ohbayashi, T. Kudo and T. Gejo, "Crystallographic, Electric and Thermochemical Properties of the Perovskite-Type $\operatorname{In}_{1-x} \mathrm{Sr}_{x} \mathrm{CoO}_{3}$ (Ln: Lanthanold)", J. of Appl. Phys., 13, $1,1-7,1974$.

12. J.F. Korionyuk, S.P. Tolochko, V.A. Lutsko and V.M. Anishchic, "Preparation and Properties of $\mathrm{La}_{1-x} \mathrm{Ca}_{x} \mathrm{CoO}_{3}(0.2<x<0.6)^{\prime \prime}$, J. of Solid State Chemistry, 48, 209-14, 1983.

13. F.R. Van Buren and J.H.W. de Wit, "The Thermoelectric Power of $\mathrm{La}_{1-x_{x}} \mathrm{Sr}_{x} \mathrm{CoO}_{3-y}$ ", J. Electrochem. Soc., 126, 1817-20, 1979.

14. B.K. Flandermeyer, M.M. Nasrallar., A.K. Agarwal and H.U. Anderson, "Defeci Structure of Mg-Doped $\mathrm{LaCrO}_{3}$ : Model and Thermogravimetric Measurements", J. Am. Cer. Soc., 67, 195, 1984.

15. F.A. Kroger and H.J. Vink, "Solid State Physics", Vol. 3, Ed., by F. Seitz and D. Turnbull, Academic Press, New York, 307, 1965.

16. H.U. Anderson, C.C. Chen and J.C. Wang, "Synthesis of Conducting Oxide Films and Fowders fiom Polymeric Precursors", Ceramic Powder processing Sc. III, Ed. G. Messing, H. Hausner and S. Hirano, Amer. Cer. Soc., 1990.

17. H.U. Anderson, M.M. Nasrallah, F. Blum and M. Smith, "Polymeric Synthesis oi Perovskite Powders and Films", Proc. Intl. Conf. on the Chemistry of Electronic Ceramic Materials, NIST SP 804, 1991.

\section{Contributors to Program}

1. Dr. H.U. Anderson, Curators' Professor of Ceramic Engineering and Senior Investigator, Materials Research Center, Principal Investigator and Program Director. 
2. Dr. Magdi M. Nasrallah, Research Professor and Co-Principal Investigator. His responsibilities include assistance with experimental details and guidance in interpretation of results.

3. Dr. Rasit Koc obtained his Ph.D. in Dec. 1989, and was supported in part by this program. He studied the stability and sintering of compositions in the $\mathrm{LaCrO}_{3}-\mathrm{LaMnO}_{3}$ $-\mathrm{LaCoO}_{3}$ system.

4. Dr. G. Carini obtained his Ph.D. in Dec. 1990, and was supported by other funds. He studied the effect of cation stoichiometry and dopants on the $\mathrm{YCrO}_{3}-\mathrm{YMnO}_{3}$ system.

5. J.D. Carter, Ph.D. candidate, supported by other funds. He is studying the mechanism of low temperature sintering and properlies of the $\mathrm{Y}_{1-x} \mathrm{Ca}_{x} \mathrm{Cr}_{1-y} \mathrm{Co}_{y} \mathrm{O}_{3}$ system.

6. J.W. Stevenson, Ph.D. candidate and supported by other funds. He is investigating the electrical and thermal characteristics of the $\mathrm{Y}_{1-\mathrm{x}} \mathrm{Ca}_{\mathrm{x}} \mathrm{MnO}_{3}$ system.

\section{Manuscripts Published or Presented}

1. "Thermal Expansion Studieo' on Cathode and Interconnect Oxides", S. Srilomsak, D.P. Schiling and H.U. Anderson, Proc. of First Intl. Symp. on Solld Oxide Fuel Cells, Ed. S. Singhal, Electrochem. Soc., (1989).

2 "Review of Defect Chemistry of $\mathrm{LaMnO}_{3}$ and $\mathrm{LaCrO}_{3}$, H.U. Anderson, J.H. Kuo and D.M. Sparlin, Proc. of First Intl. Symp. on Solid Oxide Fuel Cells, Ed. S. Singhal, Electrochem. Soc., (1989).

3. S. Seward, G. Carini and H.U. Anderson, "Structural, Sintering and Electrical Properties of the $\mathrm{YCrO}_{3}-\mathrm{YMnO}_{3}-\mathrm{YCOO}_{3}$ ", First Intl. Symp. on Solid Oxide Fuel Cells, Ed. S. Singhal, Electrochem. Soc., Hollywood, FL, Oct. 1989.

4. R. Koc and H.U. Anderson, "LaCrO 3 Based Ceramics", First Intl. Symp. on Solid Oxide Fuel Cells, Ed. S. Singhal, Electrochem. Soc., Hollywood, FL, Oct. 1989.

5. R. Koc, H.U. Anderson and M.M. Nasrallah, "Effects of Processing and Dopants on Air Sinterable LaCrO 3 ", Am. Ceram. Soc., Dallas, TX, April 1990.

6. R. Raffaelle, H.U. Anderson, D.M. Sparlin and P.E. Parris, "Transport Anomalies in the High Temperature Hopping Conductivity and Thermoelectric Power of Sr-doped $\mathrm{La}(\mathrm{Cr}, \mathrm{Mn}) \mathrm{O}_{3} "$, submitted to Physical Rev. B., August 1990.

7. R. Koc and H.U. Anderson, "Low Temperature Sintering of $\mathrm{YCrO}_{3}$ and $\mathrm{LaCrO}_{3} \mathrm{Based}$ Ceramics", Ceramic Powder Processing Science III, Ed. G. Messing, H. Hausner \& S. Hirano, Amer. Cer. Soc., 1990. 
8. H.U. Anderson, C.C. Chen, J.C. Wang and M.J. Pennell, "Synthesis of Conducting Oxide Films and Powders from Polymeric Precursors", Ceramic Powder Processing Science III, ibid.

9. H.U. Anderson, M.M. Nasrallah, F. Blum and M. Smith, "Polymeric Synthesis of Peroviskite Powders and Films", Proc. Intl. Conf. on the Chemistry of Electronic Ceramic Materials, Grand Teton, WY, August 1990.

10. H.U. Anderson, M.M. Nasrallah, R. Koc and D. Carter, "Air Sinterable Solid Oxide Fuel Cell Interconnects", 1990 Fuel Cell Seminar, Phoenix, AZ, November 25-28, 1990.

11. G.F. Carini, H.U. Anderson, D.M. Sparlin and M.M Nasrallah, "Electrical Conductivity, Seebeck Coefficient and Defect Chemistry of Ca-doped $\mathrm{YCrO}_{3}{ }^{\prime \prime}$, Accepted for publication, Solid State lonics.

12. G.F. Carini, H.U. Anderson, M.M. Nasrallah and D.M. Sparlin, "Defect Structure, Nonstoichiometry and Phase Stability of $\mathrm{Y}_{1-x} \mathrm{Ca}_{x} \mathrm{CrO}_{3}{ }^{\infty}$, Submitted, J. Solid State Chem.

13. J.W. Stevenson, M.M. Nasraliah and H.U. Anderson, "Electrical and Structural Characteristics of $\mathrm{Y}_{1-x} \mathrm{Ca}_{x} \mathrm{MnO}_{3}{ }^{\prime \prime}$, ibid.

14. D.C. Carter, M.M. Nas' allah and H.U. Anderson, "Properties of Liquid Phase Sintered $\mathrm{LaCrO}_{3}$ and $\mathrm{YCrO}_{3}$ ", Ceramic Society Meeting, Cincinnati, $\mathrm{OH}$, April 1991.

15. H.U. Anderson and G. Carini, "Defect Chemistry and Properties of $\mathrm{Y}_{1-\mathrm{x}} \mathrm{Ca}_{\mathrm{x}} \mathrm{CrO}_{3}$ ", 6th Workshop on Nonstoichiometric Compounds, Tokyo, Japan, December 3-5, 1990.

16. M.M. Nasrallah, H.U. Anderson and J.W. Stevenson, "Defect Chemistry and Properties of $\mathrm{Y}_{1-x} \mathrm{Ca}_{x} \mathrm{MnO}_{3}{ }^{n}$, 2nd International Symposium on Solid Oxide Fuel Cells, Atheris, Greece, July 2-5, 1991.

17. M.M. Nasrallah, D.C. Carter and H.U. Anderson, "Low Temperature Air-Sinterable $\mathrm{LaCrO}_{3}$ and $\mathrm{YCrO}_{3}{ }^{\prime \prime}$, ibid. 

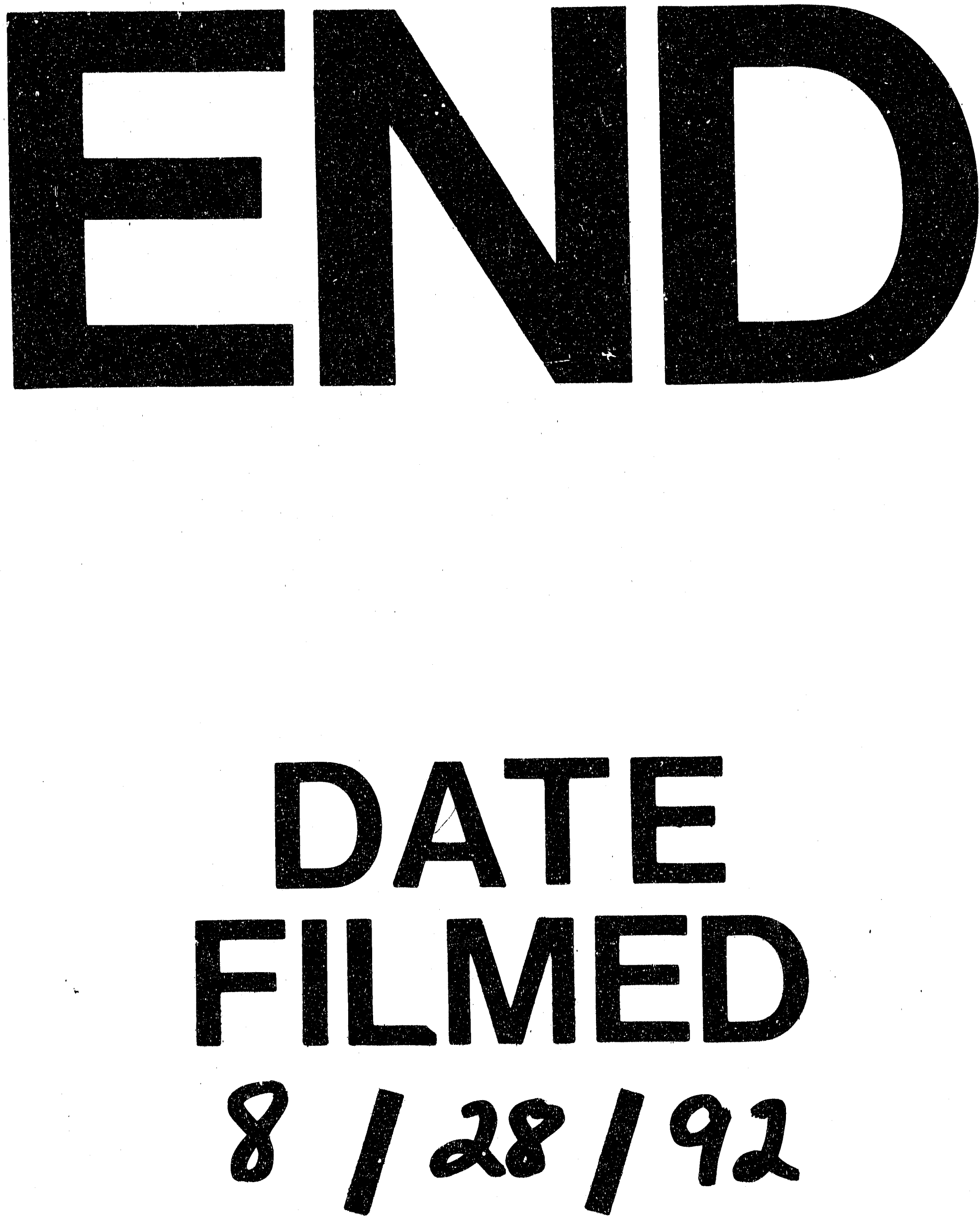

1 
